\title{
Article \\ One-Step Microwave-Assisted Synthesis of PtNiCo/rGO Electrocatalysts with High Electrochemical Performance for Direct Methanol Fuel Cells
}

\author{
Kun-Yauh Shih *, Jia-Jun Wei and Ming-Chi Tsai \\ Department of Applied Chemistry, National Pingtung University, Pingtung County 90003, Taiwan; \\ sg974408@gmail.com (J.-J.W.); mikechi614@gmail.com (M.-C.T.) \\ * Correspondence: sky@mail.nptu.edu.tw
}

check for updates

Citation: Shih, K.-Y.; Wei, J.-J.; Tsai, M.-C. One-Step

Microwave-Assisted Synthesis of $\mathrm{PtNiCo} / \mathrm{rGO}$ Electrocatalysts with High Electrochemical Performance for Direct Methanol Fuel Cells. Nanomaterials 2021, 11, 2206. https:// doi.org/10.3390/nano11092206

Academic Editors:

Diego Cazorla-Amorós and Rob Hui

Received: 29 July 2021

Accepted: 25 August 2021

Published: 27 August 2021

Publisher's Note: MDPI stays neutral with regard to jurisdictional claims in published maps and institutional affiliations.

Copyright: (C) 2021 by the authors. Licensee MDPI, Basel, Switzerland. This article is an open access article distributed under the terms and conditions of the Creative Commons Attribution (CC BY) license (https:/ / creativecommons.org/licenses/by/ $4.0 /)$.

\begin{abstract}
Platinum $(\mathrm{Pt})$ is widely used as an activator in direct methanol fuel cells (DMFCs). However, the development of $\mathrm{Pt}$ catalyst is hindered due to its high cost and $\mathrm{CO}$ poisoning. A multi-metallic catalyst is a promising catalyst for fuel cells. We develop a simple and rapid method to synthesize $\mathrm{PtNiCo} / \mathrm{rGO}$ nanocomposites (NCs). The PtNiCo/rGO NCs catalyst was obtained by microwaveassisted synthesis of graphene oxide (GO) with $\mathrm{Pt}, \mathrm{Ni}$, and Co precursors in ethylene glycol (EG) solution after heating for $20 \mathrm{~min}$. The Pt-Ni-Co nanoparticles showed a narrow particle size distribution and were uniformly dispersed on the reduced graphene oxide without agglomeration. Compared with PtNiCo catalyst, $\mathrm{PtNiCo} / \mathrm{rGO}$ NCs have superior electrocatalytic properties, including a large electrochemical active surface area (ECSA), the high catalytic activity of methanol, excellent anti-toxic properties, and high electrochemical stability. The ECSA can be up to $87.41 \mathrm{~m}^{2} / \mathrm{g}$ at a scan rate of $50 \mathrm{mV} / \mathrm{s}$. They also have the lowest oxidation potential of CO. These excellent electrochemical performances are attributed to the uniform dispersion of PtNiCo nanoparticles, good conductivity, stability, and large specific surface area of the rGO carrier. The synthesized PtNiCo/rGO nanoparticles have an average size of $17.03 \pm 1.93 \mathrm{~nm}$. We also investigated the effect of catalyst material size on electrocatalytic performance, and the results indicate that $\mathrm{PtNiCo} / \mathrm{rGO} \mathrm{NC}$ catalysts can replace anode catalyst materials in fuel cell applications in the future.
\end{abstract}

Keywords: direct methanol fuel cells; $\mathrm{PtNiCo} / \mathrm{rGO}$; graphene; microwave-assisted synthesis; nanocomposites

\section{Introduction}

Fuel cells have been considered green energy, renewable, and efficient energy devices in recent years due to environmental and energy challenges [1]. Direct methanol fuel cells (DMFCs) have attracted significant attention due to their high energy density and the abundance of liquid methanol [2,3]. The advantages of DMFCs are the simple structure of the system [4], low pollution [5], low operating temperature [6], and high energy conversion efficiency. They mainly convert methanol to produce electric energy through the catalyst of the electrode. Therefore, they can be used in small and portable electronic products such as laptops and mobile phones $[7,8]$. However, the electro-oxidation reaction of methanol is very complicated and slow, which is needed to improve the rate of electro-catalytic reaction. Moreover, the cost of DMFC systems is still very high, so the large-scale application of DMFCs is still quite limited [9].

In DMFC, methanol is oxidized to produce $\mathrm{H}^{+}, \mathrm{e}^{-}$, and $\mathrm{CO}_{2}$ according to the reaction formula $\mathrm{CH}_{3} \mathrm{OH}+\mathrm{H}_{2} \mathrm{O} \rightarrow \mathrm{CO}_{2}+6 \mathrm{H}^{+}+6 \mathrm{e}^{-}$. However, carbon-oxygen bonds in methanol are not easy to break, so the methanol electro-oxidation reaction (MOR) on the anode is critical to the overall performance of DMFCs $[10,11]$. Pt-based alloys are widely used as highly reactive anode catalysts as an important component of DMFCs [12,13]. However, Pt-based alloys are easily hindered by the formation of toxic intermediates during electrochemical 
oxidation [12,14]. To avoid catalyst poisoning and oxygen reduction reaction (ORR), PtM alloys are proposed to have enhanced performance compared to pure platinum $[13,15]$. The electrocatalytic ability of Pt alloy increases because of the ligand effect and bifunctional effect [16]. It has been reported that Pt-Ni nanocrystals always have higher electrochemical activity, and Pt-Co nanocrystals are more stable than other $\mathrm{Pt}-\mathrm{M}$ alloy materials attributed to the contribution of fine-tuned electronic structure [17]. Compared with monometallic or bimetallic catalysts, the ternary metallic catalysts have better electrochemical performance and significant catalytic activity. Therefore, adding other non-precious transition metals such as $\mathrm{Ni}, \mathrm{Co}, \mathrm{Ru}$, etc. to replace the expensive $\mathrm{Pt}$ can reduce the consumption of expensive Pt materials while maintaining excellent performance [18]. Rethinasabapathy et al. [19] synthesized ternary PtRuFe nanoparticles supported by $\mathrm{N}$-doped graphene as efficient methanol oxidation exhibiting higher ECSA. MOR activity is two to three times higher compared to other mono- and bimetallic catalysts. The addition of Fe significantly reduces the amount of Pt used in fuel cells. Other high-quality ternary PtRhCu nanocrystals with highly dendritic nanostructures were synthesized. The high specific activity and mass activity of the catalyst are due to the synergistic effect between $\mathrm{Pt}, \mathrm{Rh}$, and $\mathrm{Cu}$ elements and their highly dendritic nanostructure [20]. Sui et al. [21] prepared ternary Au@PdNi core-shell nanoparticles by a facile method. The results indicated that the electronic effects and the core-shell nanostructure played an important role in enhancing the catalytic activity and stability. They also enhanced the toxicity resistance of catalyst intermediates [22], improved the performance and durability of catalysts, and increased the overall energy conversion efficiency [23]. $\mathrm{Pt}_{1-\mathrm{x}-\mathrm{y}} \mathrm{Ir}_{\mathrm{x}} \mathrm{Ni}_{\mathrm{y}}$ nanocrystals were synthesized by a one-step process at room temperature and showed excellent tolerance to poisoning and stability [24]. In addition, ternary PtIrCu nanocrystals exhibit high durability and toxicity tolerance due to their large surface area, composition, and strain effects [25]. Lee et al. [26] developed a carbon-loaded $\mathrm{PtRuNi} / \mathrm{C}$ ternary electrocatalyst. Compared to $\mathrm{Pt} / \mathrm{C}$ and $\mathrm{PtRu} / \mathrm{C}$ catalysts, $\mathrm{PtRuNi} / \mathrm{C}$ catalysts exhibit enhanced $\mathrm{CO}$ tolerance. PtNiCo ternary alloy nanoframe crystals exhibit excellent activity and durability as efficient electrocatalysts for hydrogen evolution reaction (HER) [27]. The stable and highly efficient ordered $\mathrm{Pt}_{2} \mathrm{CoNi}$ ternary alloy electrocatalyst has 5-6 times higher electrocatalytic ORR activity than commercial $\mathrm{Pt} / \mathrm{C}$ catalysts [28]. Therefore, the ternary alloy Pt-Ni-Co nanoparticles have higher catalytic activities, better stability, and a $\mathrm{CO}$ anti-poisoning effect [29].

Several methods to prepare electrocatalysis materials have been developed. Bhunia et al. [30] exhibited a simple one-pot and one-step solvothermal synthesis of PtAuNi nanoparticles as electrocatalysts with a diameter distribution of $3-7 \mathrm{~nm}$ by heating in an oven at $200{ }^{\circ} \mathrm{C}$ for $72 \mathrm{~h}$. Sial et al. [31] used a typical hydrothermal method synthesis of trimetallic PtCoFe alloy nanosheets to obtain fuel cell catalysts with excellent electrocatalytic activity and durability. Lee et al. [26] reported that a PtRuNi/C ternary metal-based electrocatalyst can be possibly used as a CO-tolerant anode catalyst for PEMFC. In their study, a protective coating was used to prepare a product with a Pt-rich shell to prevent the $\mathrm{Ni}$ dissolution and sintering effect. Nugraha et al. [32] synthesized mesoporous AuCuNi alloy films by electrodeposition from an electrolyte solution containing three metal precursors with a micellar sacrificial template at the fixed applied potential. The mesoporous $\mathrm{AuCuNi}$ films were synthesized for nonenzymatic glucose sensing with high sensitivity, selectivity, and low detection limit. Yang et al. [13] fabricated porous Pt-Pd nanoparticles by a reflux method. Hong et al. [33] developed a galvanic replacement method to obtain Pd-Pt with Pd nanocrystals with different shapes as sacrificial templates. Wang, H. et al. [34] prepared a Pt nanocomposite by dopamine self-polymerization and a displacement reaction. Choi et al. [35] showed that extremely dispersed Pt and PtNi nanoparticles can be synthesized on supports by an impregnation process employing thiometallate precursors. $\mathrm{Pd}-\mathrm{Co}$ nanowires with a jagged appearance were obtained via the template-confined electrodeposition first and afterward excessive etching in phosphoric acid by Wang, C. et al. [14]. Wang, P. et al. [36] fabricated PtPdCu porous nanodendrites and nanocubes by using a surfactant assisted coreduction method with a solvent of water. However, the methods 
described above have several problems, including a comparatively low price-performance ratio, more elementary reaction steps, and inefficient synthesis. Therefore, more economical and novel tactics need to be utilized in the synthesis of electrocatalysts to improve catalytic properties. In this study, we found a simple, efficient, one-step synthesis, time-saving, environmentally friendly, non-metallic protective coating, and template-free method for the preparation of electrocatalysts.

Microwave irradiation indicates ultra-high frequency electromagnetic waves with a certain wavelength. The range is from $1 \mathrm{~m}$ to $1 \mathrm{~mm}$ and the frequency range of $300 \mathrm{MHz}-300 \mathrm{GHz}$ [37]. The advantages of using microwaves compared to traditional heating methods are uniform heating, high speed [38], and energy efficiency. On the other hand, the heating material does not need to be in direct contact with the heat source, so the thermal resistance effect in the heat transfer process can be reduced. Microwaveassisted heating is a simple, effective, and energy-efficient heating method that has been successfully applied in organic synthesis [39], functionalization of carbon nanotubes [40], and preparation of exfoliated graphite [41]. Pipus et al. [42] found that the esterification reaction of benzoic acid is a slow process and requires several days to reach equilibrium at $80^{\circ} \mathrm{C}$. However, microwave heating $\left(140^{\circ} \mathrm{C}, 7 \mathrm{~atm}\right)$ was able to increase the rate of the esterification reaction in a short time. Yangá Lee et al. [43] showed that the nanoparticles obtained by microwave-assisted heating with the smallest particle size could be uniformly dispersed on the carbon carrier and had high electrocatalytic activity.

In this study, a ternary metallic nanocatalyst was synthesized by the microwaveassisted method. In addition, the appropriate carbon support is also essential for the conduction of electrons and the dispersion of precious metal particles during the catalyst design process. Graphene is chosen as a carbon carrier due to its unique advantages such as large specific surface area, flexible two-dimensional structure, high mechanical property [44], and good conductivity [17]. The loading of PtNiCo nanoparticles on graphene improves the utilization of the metal and its uniform dispersion on the graphene. It contributes to the accessibility of surface active sites and electron transfer kinetics [23]. The $\mathrm{PtNiCo} / \mathrm{rGO}$ nanocomposite catalysts were prepared by GO with different ratios of $\mathrm{Pt}$, $\mathrm{Ni}$, Co precursors in an ethylene glycol solution microwave-assisted system at different temperatures for $20 \mathrm{~min}$. In this process, a reductant is used to obtain better performance to eliminate oxygen-containing functional groups [17]. The PtNiCo particles were successfully loaded on the supports and the structural characteristics of the prepared catalysts were evaluated by transmission electron microscopy (TEM), energy-dispersive $X$-ray spectroscopy (EDX), X-ray diffraction (XRD), and Raman. The electrochemical measurements included cyclic voltammetry (CV) scanning, CO stripping, and chronoamperometry (CA).

\section{Materials and Methods}

\subsection{Materials}

Graphite powder (99.99\%) and potassium hexachloroplatinate $\left(\mathrm{K}_{2} \mathrm{PtCl}_{6}, 99.99 \%\right)$ were purchased from Alfa Aesar (Haverhill, MA, USA). Sodium nitrate $\left(\mathrm{NaNO}_{3}, 99.5 \%\right)$, potassium permanganate $\left(\mathrm{KMnO}_{4}, 99.3 \%\right)$, and nickel chloride hexahydrate $\left(\mathrm{NiCl}_{2} \cdot 6 \mathrm{H}_{2} \mathrm{O}, 96 \%\right)$ were purchased from Hayashi Pure Chemical (Osaka, Japan) and cobalt(II) nitrate hexahydrate $\left(\mathrm{Co}\left(\mathrm{NO}_{3}\right)_{2} \cdot 6 \mathrm{H}_{2} \mathrm{O}, 99 \%\right)$ was purchased from JT Baker Chemicals (Phillipsburg, NJ, USA). Hydrogen peroxide $\left(\mathrm{H}_{2} \mathrm{O}_{2}, 30 \%\right)$ was purchased from Showa Chemical (Tokyo, Japan). Ethylene glycol (EG, 99.9\%) was purchased from TEDIA (Fairfield, OH, USA). Hydrochloric acid $(\mathrm{HCl},>35 \%)$ and potassium hydroxide $(\mathrm{KOH}, 85 \%)$ were purchased from Union Chemical Works (Hsinchu, Taiwan). Liquid Nafion (5 $\mathrm{wt} \%$ ) was purchased from DuPont (Wilmington, DE, USA). Sulfuric acid $\left(\mathrm{H}_{2} \mathrm{SO}_{4}, 97 \%\right)$, acetone $\left(\left(\mathrm{CH}_{3}\right)_{2} \mathrm{CO}\right.$, $95 \%)$, and methanol $\left(\mathrm{CH}_{3} \mathrm{OH}, 99.5 \%\right)$ were purchased from Nihon Shiyaku Reagent (Kyoto, Japan). Millipore water $(18 \mathrm{M} \Omega)$ was used for all electrochemistry measurements. All chemicals used in this experiment were analysis reagents (A.R.). 


\subsection{Fabrication of Graphene Oxide by a Modified Hummers Method}

GO was prepared by the modified Hummers method from graphite powder [45]. Seventy milliliters of $\mathrm{H}_{2} \mathrm{SO}_{4}$ was added to an ice bath and cooled to $5{ }^{\circ} \mathrm{C}$. Graphite powder, $\mathrm{NaNO}_{3}$, and $\mathrm{KMnO}_{4}$ were added to the flask and stirred well for $2 \mathrm{~h}$. Then, $300 \mathrm{~mL}$ of deionized water was added and the color of the solution changed to yellowish brown, then $10 \mathrm{~mL}$ of $30 \%$ hydrogen peroxide was added to stop the reaction. After suction and filtration, the sample was put into $500 \mathrm{~mL}$ of $5 \%$ hydrochloric acid to remove the metal ions, then washed repeatedly with DI water until neutral. The products were then dried overnight in an oven at $80^{\circ} \mathrm{C}$ to obtain graphene oxide.

\subsection{Preparation of Samples}

A $0.02 \mathrm{M} \mathrm{K}_{2} \mathrm{PtCl}_{6}, 0.02 \mathrm{M} \mathrm{NiCl}_{2}, 0.02 \mathrm{M} \mathrm{Co}\left(\mathrm{NO}_{3}\right)_{2}$ solution was mixed with $30 \mathrm{~mL}$ of ethylene glycol, $20 \mathrm{mg} \mathrm{GO}$, and stirred for $30 \mathrm{~min}$. The resulting homogeneous dark brown solution was adjusted to $\mathrm{pH} 10$ with $0.2 \mathrm{M} \mathrm{KOH}$ solution and transferred to $100 \mathrm{~mL}$ Teflon digestion vessels. The solution was heated at $200{ }^{\circ} \mathrm{C}$ for $20 \mathrm{~min}$ by a microwave system and then cooled to room temperature naturally. The samples were filtered and dried in an oven at $70{ }^{\circ} \mathrm{C}$. Nanocomposites at different temperatures were prepared using a similar process. $\mathrm{PtNiCo} / \mathrm{rGO}$ was synthesized at $160,180,200$, and $220^{\circ} \mathrm{C}$, labeled as PtNiCo/rGO 160, $\mathrm{PtNiCo} / \mathrm{rGO} 180, \mathrm{PtNiCo} / \mathrm{rGO} 200$, and $\mathrm{PtNiCo} / \mathrm{rGO} 220$, respectively. $\mathrm{PtNi}_{2} \mathrm{Co} / \mathrm{rGO}$, $\mathrm{PtNiCo} / \mathrm{rGO}$, and $\mathrm{PtNiCo}_{2} / \mathrm{rGO}$ were synthesized in the mole ratios of Pt:Ni:Co 1:2:1, 1:1:1, and 1:1:2, respectively. A graph of the synthesis process is shown in Figure 1.
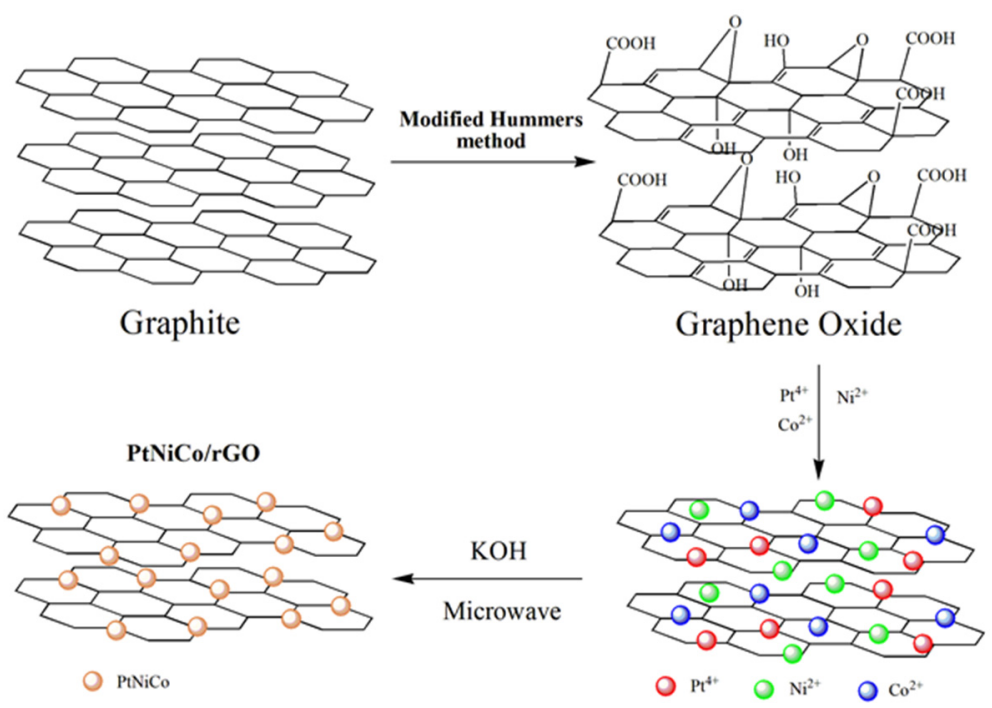

Figure 1. Illustration of the formation of the $\mathrm{PtNiCo} / \mathrm{rGO}$.

\subsection{Preparation of Catalyst Ink}

The PtNiCo/rGO ink was prepared by adding $4 \mathrm{mg}$ of sample powder to $0.8 \mathrm{~mL}$ of DI water and $0.2 \mathrm{~mL}$ of ethanol solution. The platinum working electrode was polished and used as a working electrode. It was coated with $15 \mu \mathrm{L}$ of the above catalyst ink and $15 \mu \mathrm{L}$ of Nafion ionomer, and dried at room temperature. After the electrodes were dried, electrochemical measurements could be carried out.

\subsection{Structural Catalyst Characterization}

$\mathrm{PtNiCo} / \mathrm{rGO}$ nanocomposite was synthesized by a microwave (Flexiwave T660, Milestone srl, Sorisole, Italy). The crystal structure of the samples was measured by $\mathrm{X}$-ray diffraction (XRD, D8A25 eco, BRUKER Co. Ltd., Billerica, MA, USA) with CuK $\alpha$ X-ray radiation $(\lambda=1.5418 \AA$ ) at $40 \mathrm{kV}$ and $25 \mathrm{~mA}$. The morphology of the samples was observed by transmission electron microscopy (TEM, Hitachi H-7500, Tokyo, Japan) with an accelerating voltage of $80 \mathrm{kV}$. The elemental composition of the prepared nanocomposites was 
analyzed by energy dispersive $X$-ray analysis (EDS, INCA x-act) equipped with scanning electron microscopy (SEM, JEOL JSM-6390, Tokyo, Japan). Raman spectra were analyzed with a nitrogen-cooled CCD detector (Shamrock 750 spectrograph, Andor Technology Ltd., Belfast, Northern Ireland, UK). A randomly polarized $533 \mathrm{~nm}$ laser with an excitation power of $0.45 \mathrm{~mW}$ was used.

\subsection{Electrochemical Characterization}

The electrochemical measurements were carried out on a Bio-Logic CLB-500 electrochemical Workstation (Knoxville, TN, USA) at room temperature. The electrochemical test was carried out with a three-electrode apparatus: a platinum working electrode (diameter: $2 \mathrm{~mm}$ ), a Pt wire, and Ag/ AgCl electrodes as the working, counter, and reference electrodes, respectively. The measured potentials are all compared with $\mathrm{Ag} / \mathrm{AgCl}$ electrodes for convenience of comparison. Cyclic voltammetry (CV), CO stripping, and chronoamperometry (CA) were employed to estimate the electrochemical activity and stability of catalysts. $\mathrm{CV}$ and $\mathrm{CA}$ techniques were employed to measure at room temperature and in a $\mathrm{N}_{2}$ saturated environment, while CO stripping is tested under saturated CO gas. The ECSA was calculated from the hydrogen desorption peak of the $\mathrm{CV}$ method in $0.5 \mathrm{M} \mathrm{H}_{2} \mathrm{SO}_{4}$ electrolyte, which was conducted by cycling the potential between -0.25 and $1.0 \mathrm{~V}$, with a scan rate of $50 \mathrm{mV} / \mathrm{s}$. CO stripping evaluates the ability of the catalyst to metabolize toxic substances, and its scanning potential is between -0.2 and $1.0 \mathrm{~V}$, carried out in $0.5 \mathrm{M}$ $\mathrm{H}_{2} \mathrm{SO}_{4}$ electrolyte. Electrochemical activity and catalytic ability of the catalysts for MOR were determined by $\mathrm{CV}$ and $\mathrm{CA}$ methods in $0.5 \mathrm{M} \mathrm{H}_{2} \mathrm{SO}_{4}+1.0 \mathrm{M} \mathrm{CH}_{3} \mathrm{OH}$ electrolytic solution.

\section{Results and Discussion}

\subsection{Characterization of PtNiCo/rGO \\ 3.1.1. XRD Analysis}

The crystal structure of nanocomposites was analyzed by powder XRD. The diffraction peaks of these Pt-rich phases are fase center cubic (fcc) structures (Figure 2a) [17]. Note that the peaks become progressively broader after thermal treatment. The diffraction peaks are located at the corresponding angles of $39.7^{\circ}, 46.2^{\circ}$, and $67.4^{\circ}$, and the lattice constants are (111), (200), and (220) diffraction lattice planes, respectively. The diffraction peaks of $\mathrm{Ni}$ and $\mathrm{Co}$ are located at the top of the diffraction peak, corresponding to the angles of $44.5^{\circ}, 51.8^{\circ}, 76.4^{\circ}$ and $43.7^{\circ}, 51.0^{\circ}, 74.7^{\circ}$, respectively. Based on the Joint Committee on Powder Diffraction Standards (JCPDS) card number \#04-0802, it is determined that Pt metal represents Pt (111), Pt (200), Pt (220) crystallographic planes. In the PtNiCo/rGO 160, PtNiCo/rGO 180, PtNiCo/rGO 200, and PtNiCo/rGO 220 samples, we found a much broader peak at $2 \theta=26^{\circ}$, while the diffraction peak at $2 \theta=11.9^{\circ}$ disappeared significantly. This indicates that GO has been reduced to rGO (Figure $2 \mathrm{~b}$ ). The diffraction peak at $26^{\circ}$ can be marked as rGO, with no additional peaks for phase separation structures such as pure $\mathrm{Ni}$ or $\mathrm{Co}$. This indicates an excellent degree of alloying between $\mathrm{Pt}, \mathrm{Ni}$, and Co [46]. The XRD results showed that the diffraction peaks of $\mathrm{Ni}$ and $\mathrm{Co}$ in composites are not obvious and may be related to the small amount of $\mathrm{Ni}$ and $\mathrm{Co}$ in composites [47-49]. However, the presence of $\mathrm{Ni}$ and $\mathrm{Co}$ can also be explained by a slight shift of the $\mathrm{Pt}$ (111) peak to a higher angle in the XRD analysis. The peak position of Pt (111) shifts to higher $2 \theta$ values due to the introduction of smaller $\mathrm{Ni}$ and $\mathrm{Co}$ atoms, resulting in reduced lattice distances and a composite with Pt to form the PtNiCo ternary alloy $[28,50,51]$. The catalysts exhibited broader shoulder peaks, assigned to the characteristic peak of the rGO support [52]. Moreover, the higher diffraction shifts of Pt (111) of the synthesized nanocomposites at $200{ }^{\circ} \mathrm{C}$ indicate that the synthesis is relatively complete and PtNiCo ternary alloy is better. 

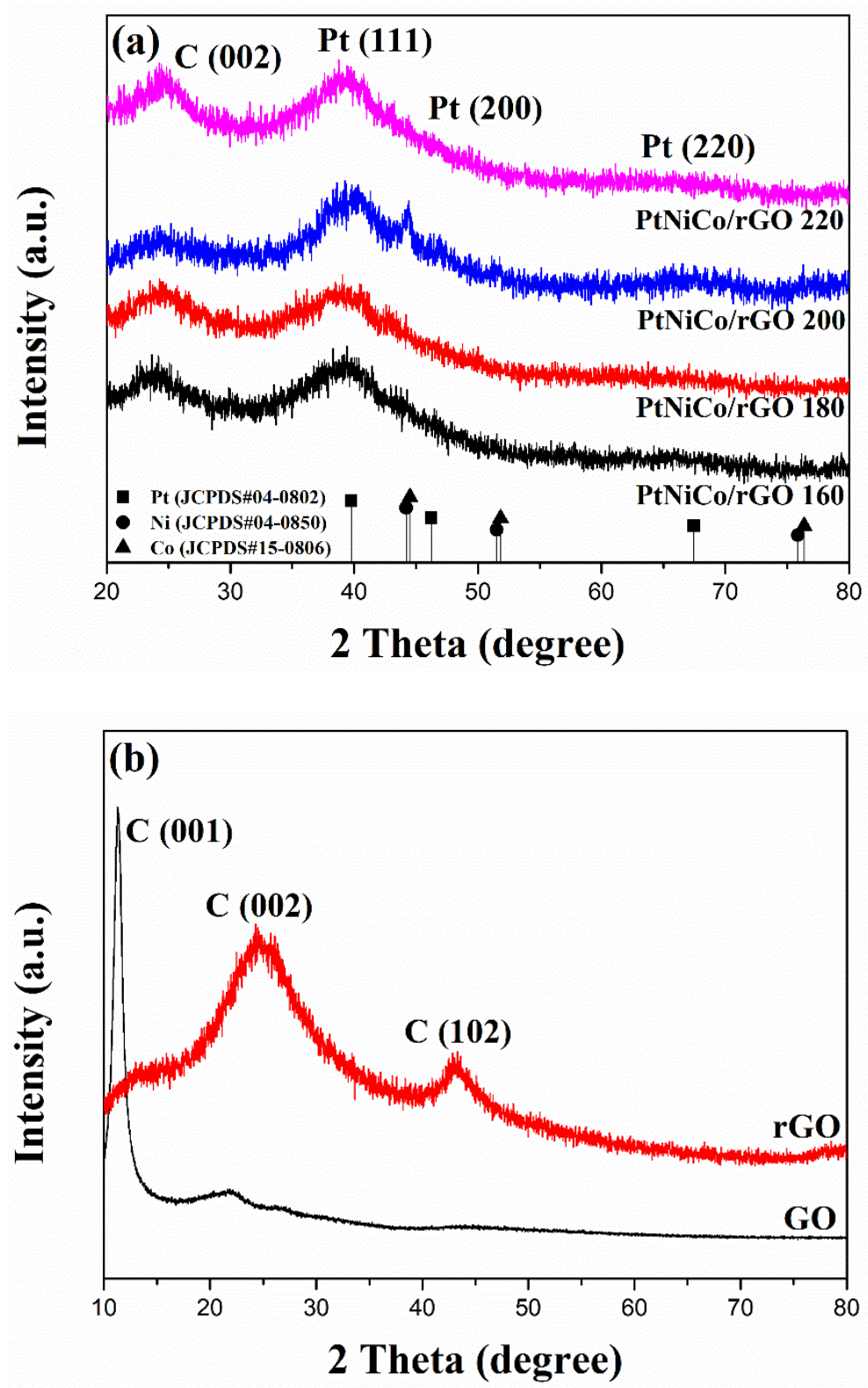

Figure 2. XRD patterns of (a) PtNiCo/rGO of different temperatures. (b) GO and rGO.

\subsubsection{Morphological Characterization}

Figure $3 \mathrm{a}-\mathrm{c}$ show the synthesized $\mathrm{PtNiCo} / \mathrm{rGO}$ ternary alloys with different ratios. The morphology of the ternary alloy / reduced graphene oxide nanocomposite was analyzed by TEM. Moreover, the dispersion of the catalyst was observed to find the optimum ratio of the atomic catalyst. In these samples, the TEM diagrams display two-dimensional images of $\mathrm{PtNiCo} / \mathrm{rGO} 200$ and $\mathrm{PtNiCo}_{2} / \mathrm{rGO} 200$ with a characteristic size of about $17.03 \pm 1.93 \mathrm{~nm}$ and $22.28 \pm 3.09 \mathrm{~nm}$ (Figure $4 \mathrm{a}, \mathrm{b}$ ). The ternary alloy PtNiCo/rGO 200 has an average particulate size of less than 20 nanometers. 


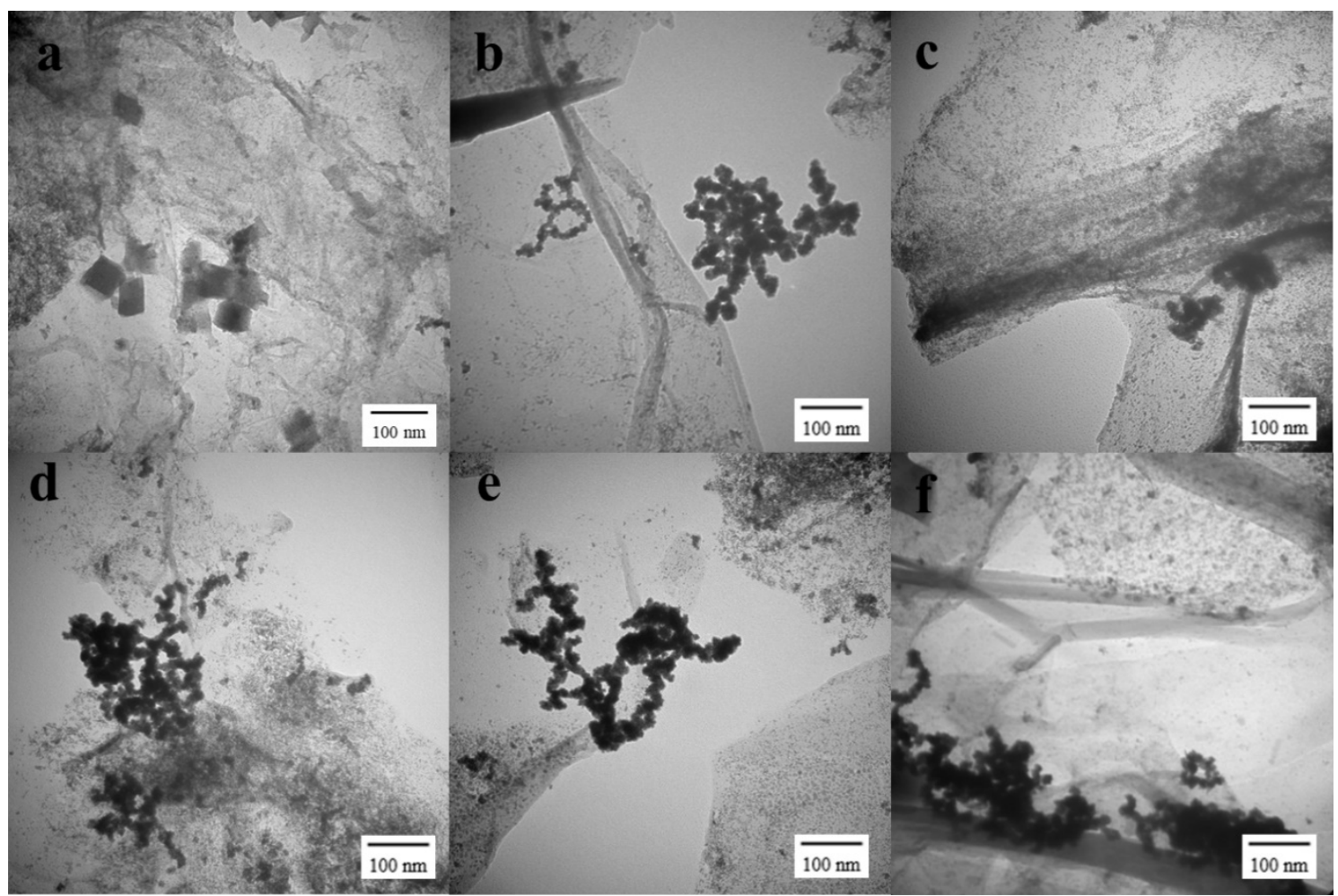

Figure 3. Morphology and structural characterization. TEM images of (a) $\mathrm{PtNi}_{2} \mathrm{Co} / \mathrm{rGO} 200$, (b) $\mathrm{PtNiCo} / \mathrm{rGO} 200$, (c) $\mathrm{PtNiCo}_{2} / \mathrm{rGO}$ 200, (d) PtNiCo/rGO 160, (e) PtNiCo/rGO 180, (f) PtNiCo/rGO 220.
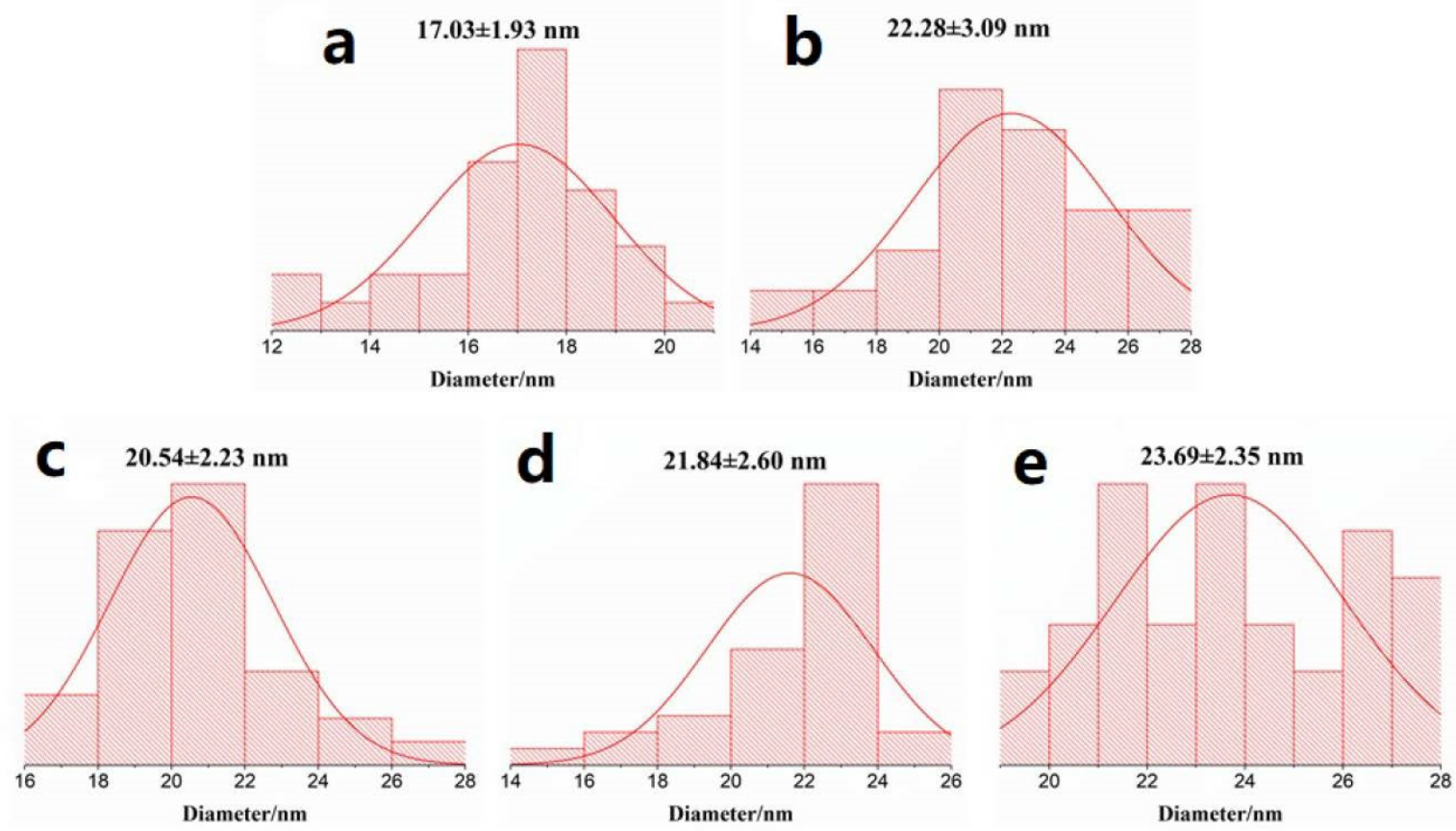

Figure 4. Particle size distribution of (a) PtNiCo/rGO 200, (b) $\mathrm{PtNiCo}_{2} / \mathrm{rGO}$ 200, (c) $\mathrm{PtNiCo} / \mathrm{rGO}$ 160, (d) PtNiCo/rGO 180, (e) $\mathrm{PtNiCo} / \mathrm{rGO} 220$.

Furthermore, $\mathrm{PtNiCo} / \mathrm{rGO}$ in Figure 3 shows a large number of PtNiCo nanoparticles surrounded by the rGO nanosheets. The metal precursor solutions were reduced to PtNiCo ternary alloy nanoparticles with ethylene glycol at different microwave temperatures, which were dispersed on the surface or embedded in the layered structure of $\mathrm{rGO}$, as 
shown in Figure 3d-f. The 2D sheet-like structure and slight folds can be observed in TEM images. Figure 4 shows the particle size and distribution of various samples and various reaction conditions. The particles formed gradually at $160^{\circ} \mathrm{C}$ and $180{ }^{\circ} \mathrm{C}$, but the reaction showed that the metal ions did not fully composite into the ternary metallic nanoparticles. The particles have a mean radius of about $21 \mathrm{~nm}$ and a wide distribution width. The particle size decreases as the temperature rises to $200{ }^{\circ} \mathrm{C}$. This is due to the larger number of seeds growing and the particles reacting more thoroughly. The metal ions can be converted to ternary metallic nanoparticles and exhibit an average radius of $17.03 \pm 1.93 \mathrm{~nm}$ and a narrower distribution width. Larger particles are formed as the temperature increases (Figure $4 a, b$ ). At this time, the agglomeration mechanism leads to more clusters agglomerating at higher temperatures and forming nanoparticles [53]. The results show that the average particle size of the synthesized nanoparticles at $200{ }^{\circ} \mathrm{C}$ is the smallest, $17 \mathrm{~nm}$, and has a relatively dispersed structure compared with other synthesis conditions. The main reason for the small particle size is the short time and fast rate of nucleation at optimal temperature conditions [54,55]. Under other synthesis conditions, the average particle size was about $20 \mathrm{~nm}$ (Figure 4). The temperature-dependent agglomeration is the dominant mechanism of the particle size difference $[56,57]$. The results showed that the dispersed PtNiCo nanoparticles were easily grown on rGO and were active on electrochemical properties [58].

The composition of the synthesized nanocomposites was obtained by energy dispersive X-ray analysis (EDS) equipped with SEM for evaluation. The EDX spectrum of $\mathrm{PtNiCo} / \mathrm{rGO} 200$ in Figure 5 shows that it consists mainly of three metal elements, Pt, $\mathrm{Ni}$, and $\mathrm{Co}$, in the sample. The peaks of $\mathrm{Ni}$ and Co can be clearly detected in the EDX image, and the atomic percentages of $\mathrm{Pt}, \mathrm{Ni}$, and $\mathrm{Co}$ are $2.73,2.67$, and $2.69 \%$, respectively. The atomic composition of the composite is almost identical to that of the metal precursor solution. The EDX image demonstrates the presence of $\mathrm{C}$ elements in $\mathrm{rGO}$, while $\mathrm{O}$ elements are mainly derived from residual oxygen-containing functional groups in rGO. Other elements can also be observed in the figure, mainly added from the material during the experiments. The appearance of $\mathrm{Cu}$ peaks originates from the copper gels used in the analysis [59]. The EDX images provide evidence for the presence of $\mathrm{Pt}, \mathrm{Ni}, \mathrm{Co}, \mathrm{rGO}$, and $\mathrm{PtNiCo}$ atomic ratios in the electrocatalyst.

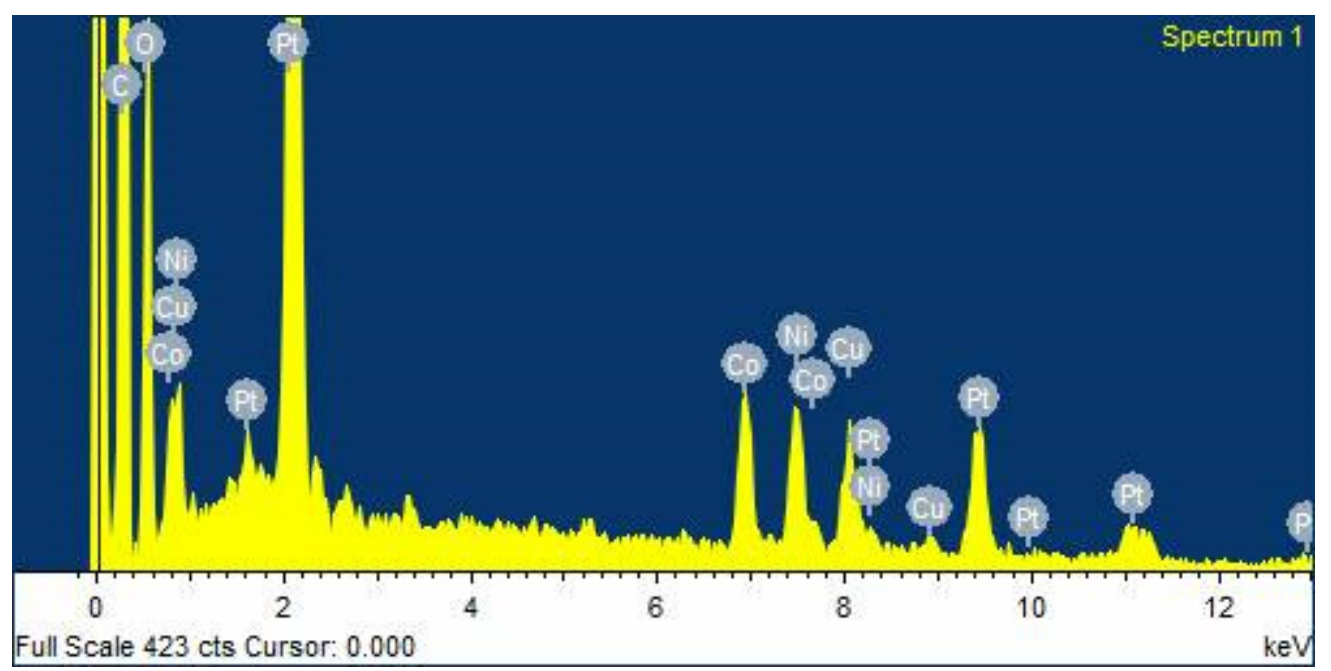

Figure 5. EDX spectrum of $\mathrm{PtNiCo} / \mathrm{rGO} 200$ composite.

\subsubsection{Raman Spectrum}

Figure 6a shows the Raman spectra of the samples in the range of $1000-3000 \mathrm{~cm}^{-1}$. They all display obvious $\mathrm{D}$ bands and $\mathrm{G}$ bands originating from carbon $\mathrm{sp}^{2}$ domains and structural defects [60]. The $G$ band is attributed to the $E_{2 g}$ mode of $C$ sp$^{2}$ atoms and the $D$ band arises due to the $\mathrm{A}_{1 \mathrm{~g}}$ symmetry [61]. The structural disorder of a graphitic structure 
could be estimated according to the $\mathrm{I}_{\mathrm{D}} / \mathrm{I}_{\mathrm{G}}$. It can be seen from Figure $6 \mathrm{a}, \mathrm{b}$ that the Dband and G-band of GO, rGO, PtNiCo/rGO 160, PtNiCo/rGO 180, PtNiCo/rGO 200, and $\mathrm{PtNiCo} / \mathrm{rGO} 220$ were $1339 \mathrm{~cm}^{-1}$ and $1586 \mathrm{~cm}^{-1}, 1346 \mathrm{~cm}^{-1}$ and $1594 \mathrm{~cm}^{-1}, 1356 \mathrm{~cm}^{-1}$ and $1590 \mathrm{~cm}^{-1}, 1356 \mathrm{~cm}^{-1}$ and $1596 \mathrm{~cm}^{-1}, 1358 \mathrm{~cm}^{-1}$ and $1594 \mathrm{~cm}^{-1}$, and $1363 \mathrm{~cm}^{-1}$ and $1590 \mathrm{~cm}^{-1}$, respectively. The $\mathrm{I}_{\mathrm{D}} / \mathrm{I}_{\mathrm{G}}$ of $\mathrm{GO}, \mathrm{rGO}, \mathrm{PtNiCo} / \mathrm{rGO} 160, \mathrm{PtNiCo} / \mathrm{rGO}$ 180, PtNiCo/rGO 200, and PtNiCo/rGO 220 were 0.81, 1.07, 1.16, 1.15, 1.18, and 1.15, respectively. Afterwards, $\mathrm{GO}$ was reduced to $\mathrm{rGO}$ because large numbers of $\mathrm{sp}^{3}$ carbon were reduced to $\mathrm{sp}^{2}$ carbon, which increases the $\mathrm{I}_{\mathrm{D}} / \mathrm{I}_{\mathrm{G}}$ value. In general, the $\mathrm{D}$-band and G-band intensities were reduced after the PtNiCo nanoparticles were composited with reduced graphene oxide. This is because the exposred area of the rGO sheet to the excitation light in PtNiCo/rGO nanocomposite is reduced in Raman measurements. The broadening of the D-band and G-band of the nanocomposite is caused by the lattice strain between rGO and PtNiCo [62].
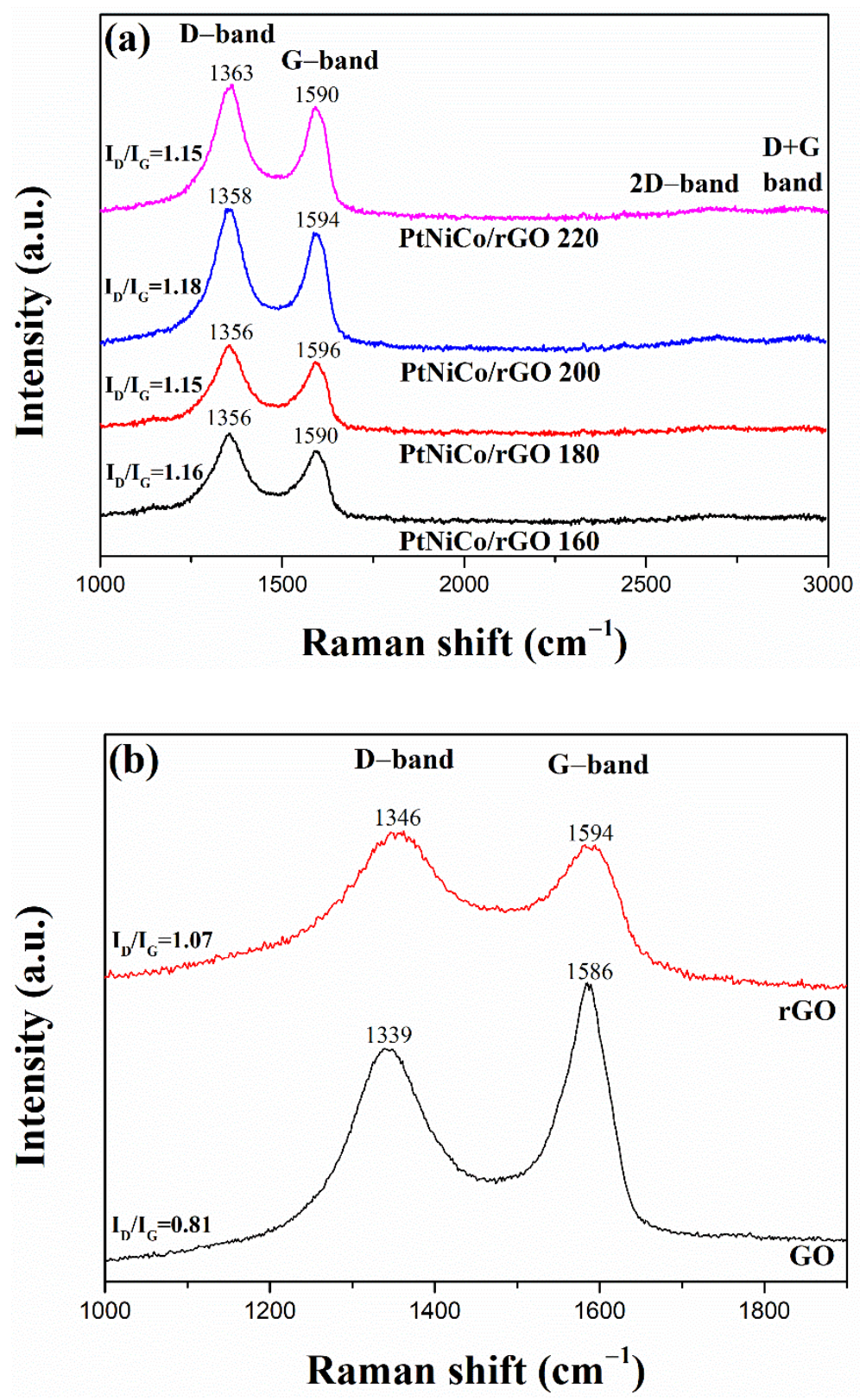

Figure 6. Raman spectra of (a) PtNiCo/rGO at various temperatures. (b) GO and rGO. 
The $\mathrm{I}_{\mathrm{D}} / \mathrm{I}_{\mathrm{G}}$ value of $\mathrm{PtNiCo} / \mathrm{rGO}$ is higher than that of $\mathrm{GO}$, indicating that the double bond of GO is broken and composited with metal nanoparticles. The larger the $\mathrm{I}_{\mathrm{D}} / \mathrm{I}_{\mathrm{G}}$ value, the more successfully the sample is composited [19]. In addition, the $\mathrm{I}_{\mathrm{D}} / \mathrm{I}_{\mathrm{G}}$ ratio could be related to the existence of defects in graphene structure as a result of electronic interaction with PtNiCo metal nanoparticles, affirming the reduction of the functional groups during microwave-assisted treatment. These defects introduced by GO act as the anchoring sites for the attachment of PtNiCo metal nanoparticles. According to the description in the literature, the increase in the intensity is related to the PtNiCo nanoparticles incorporated into the rGO as both peaks increased similarly in intensity [63]. A higher degree of graphitization is beneficial to promote the overall conductivity of the final product and enhance the electrochemical activity. In addition, the crystallinity of the $2 \mathrm{D}$ band (about $2700 \mathrm{~cm}^{-1}$ ) in $\mathrm{PtNiCo} / \mathrm{rGO} 200$ is higher, which is predicted to be more corrosion resistant in DMFC [61]. The wide 2D band shows the multilayer structure of rGO, affirming the existence of graphene and mainly coming from a double resonance process that links phonons to the electronic band structure [64]. The 2D and D + G band peaks, near 2700 and $2900 \mathrm{~cm}^{-1}$, correspond to the combination mode induced by the disorder.

\subsection{Electrochemical Measurements}

\subsubsection{CV and Mass Activity Analysis}

To obtain the ECSA of the catalysts, they were prepared as a slurry and coated on the $\mathrm{Pt}$ working electrode. In this study, CV was used to measure and analyze the characteristics of the catalysts. Figure 7 shows the $C V$ curves of the different catalysts recorded in $\mathrm{N}_{2}$-purged sulfuric acid solution at a scan rate of $50 \mathrm{mV} / \mathrm{s}$ in the potential range of $-0.2 \mathrm{~V}$ to $1.0 \mathrm{~V}$. CV curves are divided into three parts to show the typical $\mathrm{Pt}-\mathrm{H}$ under the potential deposition region, double-layer region, and Pt oxide region. Typical absorption and desorption of hydrogen occur in the low potential region. There is a significant redox peak from -0.2 0.1 V, indicating the adsorption/desorption of hydrogen on Pt [65].

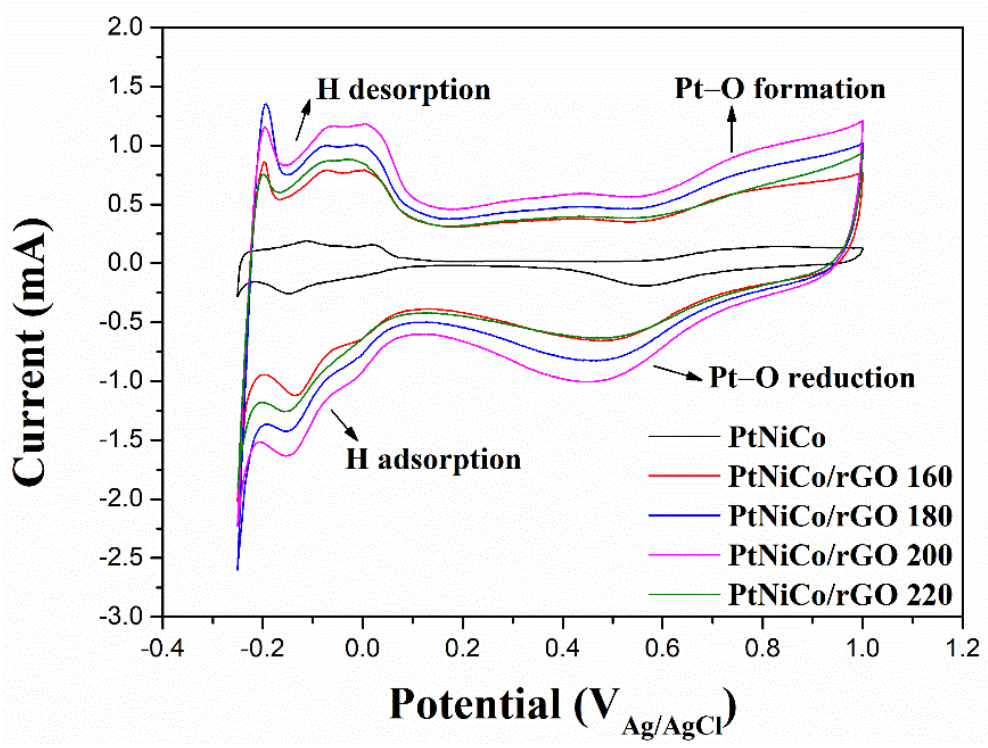

Figure 7. Electrocatalytic performance of PtNiCo, $\mathrm{PtNiCo} / \mathrm{rGO} 160, \mathrm{PtNiCo} / \mathrm{rGO} 180, \mathrm{PtNiCo} / \mathrm{rGO}$ 200, and PtNiCo/rGO 220 catalysts. Cyclic voltammograms obtained at room temperature in $\mathrm{N}_{2}$-purged $0.5 \mathrm{M} \mathrm{H}_{2} \mathrm{SO}_{4}$ aqueous solution at scan rate of $50 \mathrm{mV} / \mathrm{s}$.

The corresponding ECSA was calculated by integrating the hydrogen desorption zones and all the CV curves were normalized. According to the following formula [66]:

$$
\operatorname{ECSA}\left(\mathrm{cm}^{2} \mathrm{~g}^{-1}\right)=\frac{\text { charge }\left(Q_{H}, \mu \mathrm{C} \mathrm{cm}{ }^{-2}\right)}{210\left(\mu \mathrm{C} \mathrm{cm}^{-2}\right) \times \text { electrodeloading }\left(\mathrm{g} \mathrm{Ptcm}^{-2}\right)}
$$


where $Q_{\mathrm{H}}\left(\mu \mathrm{C} \mathrm{cm}{ }^{-2}\right)$ is the hydrogen desorption charge, $\left.210(\mu \mathrm{C} \mathrm{cm})^{-2}\right)$ is the charge required to oxidize the layer of hydrogen on $\mathrm{Pt}$, and the electrode loading $\left(\mathrm{g} \mathrm{Pt} \mathrm{cm}^{-2}\right)$ is the $\mathrm{Pt}$ working electrode loading. The individual ECSAs of these catalysts were measured as $18.19,61.43,82.65,87.41$, and $41.41 \mathrm{~m}^{2} / \mathrm{g}$ for PtNiCo, PtNiCo/rGO $160, \mathrm{PtNiCo} / \mathrm{rGO}$ 180, $\mathrm{PtNiCo} / \mathrm{rGO} 200$, and $\mathrm{PtNiCo} / \mathrm{rGO} 220$. The PtNiCo/rGO $200 \mathrm{ECSA}$ is larger than the others because of the dispersed and well-anchored Pt nanoparticles on the surface of rGO nanocomposites. The nanocomposite of $200^{\circ} \mathrm{C}$ has a good distribution of fine $\mathrm{PtNiCo}$ nanoparticles, which is attributed to the largest ECSA. This result can be seen from the TEM image, which has the smallest particle size distribution under the $200^{\circ} \mathrm{C}$ condition.

To investigate the different ratio catalysts in terms of the catalytic activity of methanol oxidation, CV measurements were performed (Figure 8). In the forward scan, the positive scan anode peak is about $0.7 \mathrm{~V}$ compared to $\mathrm{Ag} / \mathrm{AgCl}$, which is caused by the oxidation of methanol. In the reverse scan, the oxidation peak appears at about $0.5 \mathrm{~V}$, possibly owing to incompletely oxidized carbonic matters formed in the forward scan. The current density of CVs at $\sim 0.7 \mathrm{~V}$ on PtNiCo/rGO 200 is $196.82 \mathrm{~mA} \mathrm{~cm}^{-2}$, which is about 2.5 times larger than the PtNiCo $\left(80.89 \mathrm{~mA} \mathrm{~cm}^{-2}\right)$. To clearly illustrate the catalytic capacity, MOR performance is compared by normalizing peak currents to specific areas and qualities of Pt expressed as mass activity [67]. The mass activity of all catalysts is shown in Figure 9. It can be observed that $\mathrm{PtNiCo} / \mathrm{rGO} 200$ has the highest mass activity $\left(102.96 \mathrm{~mA} \mathrm{mg}^{-1}\right)$ compared with other catalysts, indicating that the $\mathrm{PtNiCo} / \mathrm{rGO} 200$ catalysts had the highest catalytic activity for MOR.

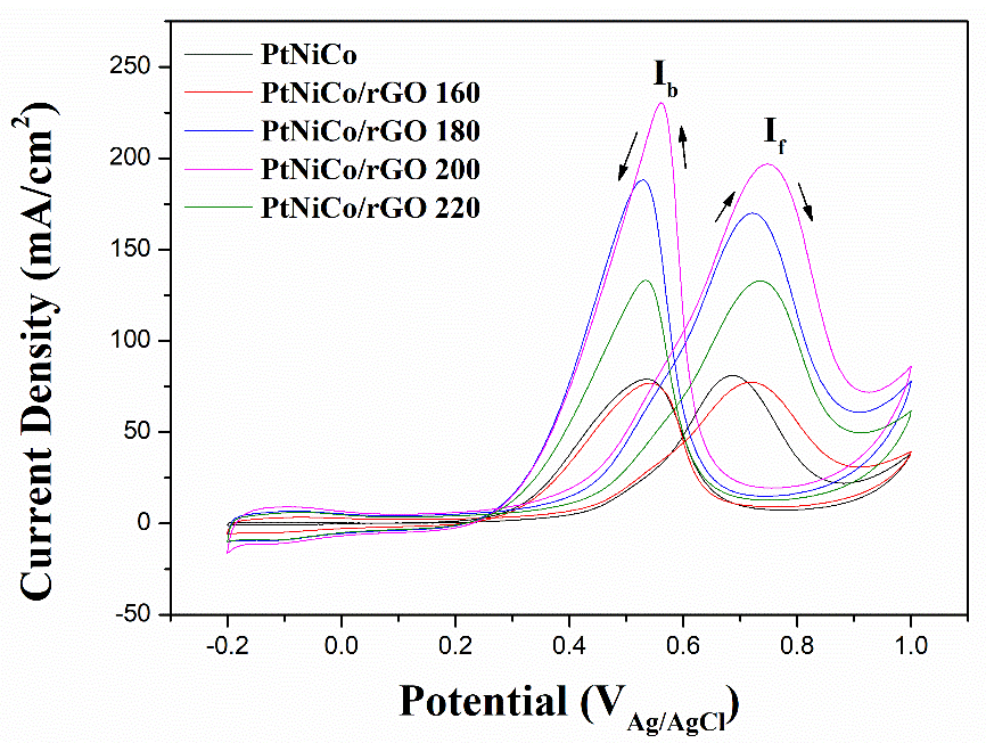

Figure 8. $\mathrm{CV}$ curves of methanol oxidation on $\mathrm{PtNi}_{2} \mathrm{Co} / \mathrm{rGO}, \mathrm{PtNiCo} / \mathrm{rGO}, \mathrm{PtNiCo}$, and $\mathrm{PtNiCO}_{2} / \mathrm{rGO}$ in $\mathrm{N}_{2}$-saturated $0.5 \mathrm{M} \mathrm{H}_{2} \mathrm{SO}_{4}+1.0 \mathrm{M} \mathrm{CH}_{3} \mathrm{OH}$ solution, sweep rate $20 \mathrm{mV} / \mathrm{s}$.

The results show that $\mathrm{PtNiCo} / \mathrm{rGO} 200$ has the highest catalytic activity and mass activity in these synthesized catalysts. The high performance of $\mathrm{PtNiCo} / \mathrm{rGO}$ is attributed to the electronic state of $\mathrm{Pt}$, which is mainly because the crystal structure and electronic structure of Pt nanoparticles can be changed by introducing other metals, thus improving the binding energy between $\mathrm{Pt}$ and toxic species $[9,68]$. In addition, the TEM images of $\mathrm{PtNiCo} / \mathrm{rGO} 200$ can significantly improve the catalytic activity due to the dispersion of small PtNiCo nanoparticles on rGO [59]. This is attributed to the fact that the presence of $\mathrm{Ni}$ and $\mathrm{Co}$ can mitigate $\mathrm{Pt}$ poisoning, resulting in the higher electrochemical activity of $\mathrm{PtNiCo} / \mathrm{rGO}[69,70]$. From the Raman spectrum, PtNiCo/rGO 200 has the highest $\mathrm{I}_{\mathrm{D}} / \mathrm{I}_{\mathrm{G}}$ intensity, meaning that a greater degree of composite PtNiCo and rGO, which will also enhance the electrocatalytic activity [71]. 


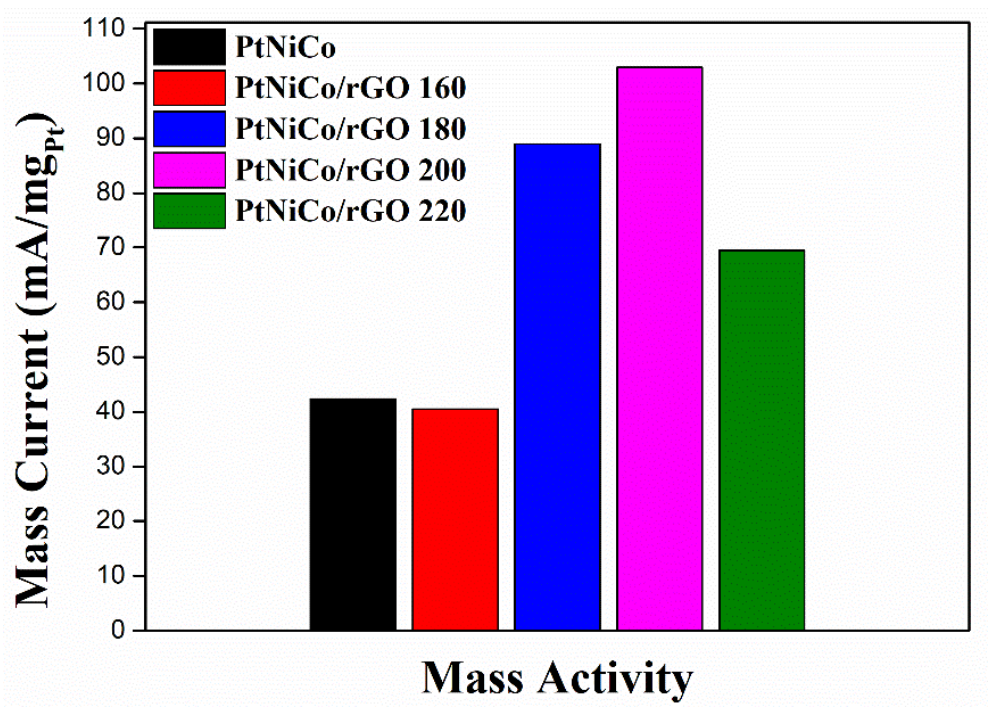

Figure 9. Histogram of mass activities of different catalysts for MOR.

\subsubsection{CO Stripping Measurements}

$\mathrm{CO}$ stripping experiments were carried out on the oxidative removal of $\mathrm{CO}$. The $\mathrm{CO}$ gas is pumped to make the $\mathrm{CO}$ adhere to the catalyst at a lower potential, and then the $\mathrm{CV}$ test is carried out. Figure 10 shows the voltammograms of $\mathrm{CO}$ oxidation for various samples at various peak potentials. In addition, the $\mathrm{CO}$ oxidation potentials (vs. $\mathrm{Ag} / \mathrm{AgCl}$ ) of $\mathrm{PtNiCo} / \mathrm{rGO}$ 160, PtNiCo/rGO 180, PtNiCo/rGO 200, and PtNiCo/rGO 220 were $0.69 \mathrm{~V}, 0.64 \mathrm{~V}, 0.62 \mathrm{~V}$, and $0.65 \mathrm{~V}$ vs. $\mathrm{Ag} / \mathrm{AgCl}$, respectively. These peaks disappear after the first scan in the forward direction. The $\mathrm{PtNiCo} / \mathrm{rGO} 200$ expresses a more negative peak potential and onset potential, indicating that the affinity between $\mathrm{Pt}$ and $\mathrm{CO}$ is weakened [72]. The results show that the introduction of $\mathrm{Ni}$ and Co elements can improve the oxidation ability of $\mathrm{CO}$ [73]. The electronic interaction between $\mathrm{Pt}, \mathrm{Ni}$, and Co could lead to the removal of $\mathrm{CO}$ poisoning substances and enhance the stability of the electrodes. Therefore, there are fewer intermediates adsorbed on the surface of PtNiCo/rGO 200, and the oxidation efficiency of $\mathrm{CO}_{\text {ads }}$ is higher, which is beneficial to increase catalytic active sites [73].

The synergistic effect of $\mathrm{CO}$ electrooxidation can be clearly seen from the oxidation onset potential to more negative values. Due to the catalytic effect, PtNiCo/rGO 200 could activate $\mathrm{CO}$ at lower potentials than the other catalysts. This result also contributes to illustrating the higher activity of $\mathrm{PtNiCo} / \mathrm{rGO}$ for the oxidation of methanol at $200{ }^{\circ} \mathrm{C}$ [74].

Table 1 shows the comparison of the ECSA, forward peak current density for methanol oxidation, and $\mathrm{CO}$ oxidation potential of $\mathrm{PtNiCo} / \mathrm{rGO} 200$ to those of various electrocatalysts investigated in previous studies. The ECSA and methanol oxidation current density of $\mathrm{PtNiCo} / \mathrm{rGO} 200$ were higher than those of the other materials previously studied. These results indicated the enhanced $\mathrm{Pt}$ hydrogen absorption/desorption area and methanol electrocatalytic activity of $\mathrm{PtNiCo} / \mathrm{rGO} 200$. In addition, the $\mathrm{CO}$ oxidation potential of $\mathrm{PtNiCo} / \mathrm{rGO} 200$ was mostly lower than other materials, showing better $\mathrm{CO}$ anti-poisoning ability. 

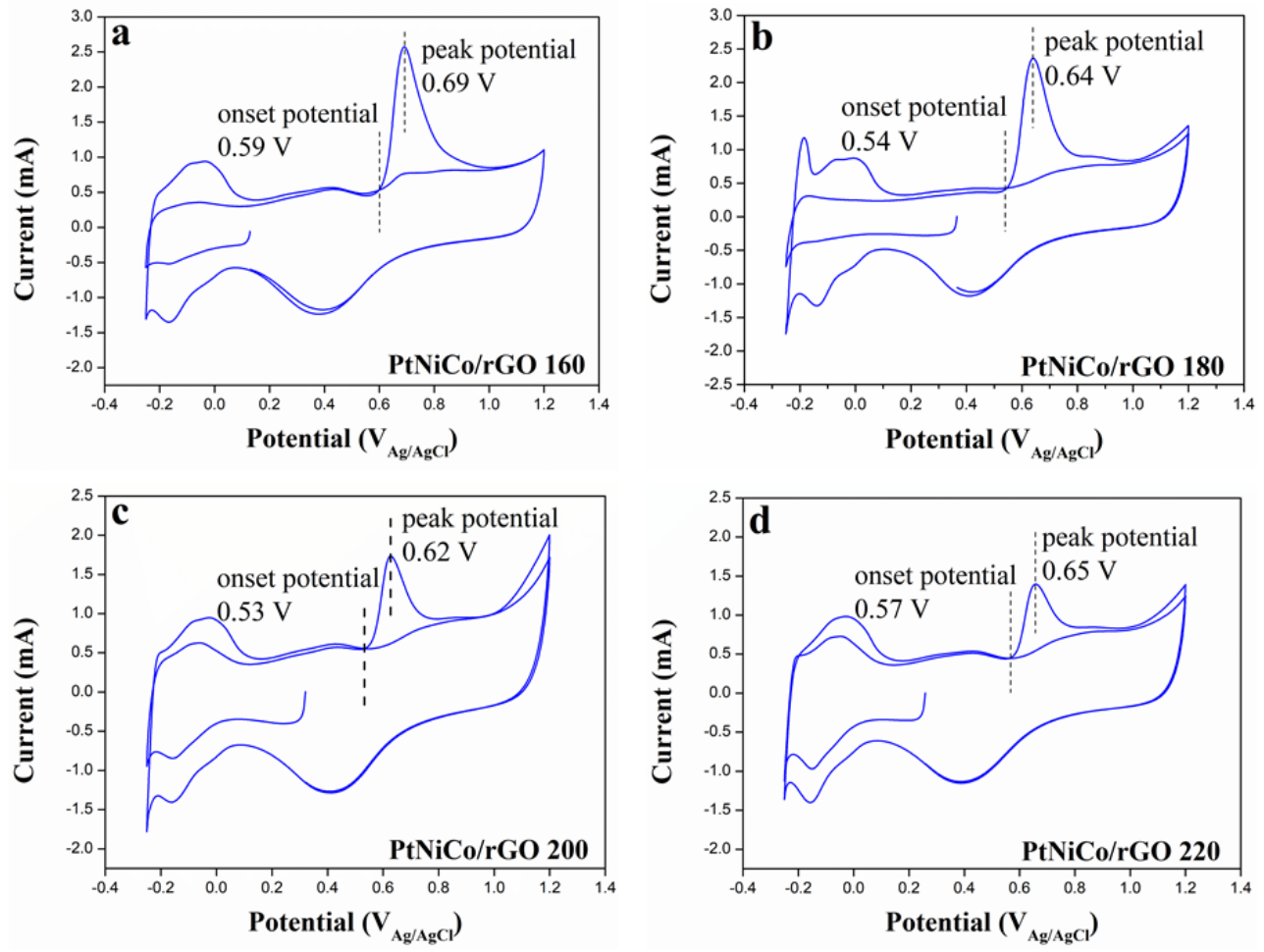

Figure 10. CO stripping curves of (a) PtNiCo/rGO 160, (b) PtNiCo/rGO 180, (c) $\mathrm{PtNiCo} / \mathrm{rGO} 200$, and (d) $\mathrm{PtNiCo} / \mathrm{rGO} 220$ in $\mathrm{CO}$-purged $0.5 \mathrm{M} \mathrm{H}_{2} \mathrm{SO}_{4}$ solution at scan rate of $50 \mathrm{mV} / \mathrm{s}$.

Table 1. ECSA and current density of methanol oxidation of various electrocatalysts in previous works.

\begin{tabular}{|c|c|c|c|c|}
\hline Electrocatalyst & $\operatorname{ECSA}\left(\mathrm{m}^{2} / \mathrm{g}\right)$ & Current Density $\left(\mathrm{mA} \mathrm{cm}^{-2}\right)$ & CO Stripping (V) & References \\
\hline $\mathrm{PtNiCo} / \mathrm{rGO} 200$ & 87.41 & 196.82 & 0.62 vs. $\mathrm{Ag} / \mathrm{AgCl}$ & This work \\
\hline $\mathrm{Pt} / \mathrm{BG}$ & 58.8 & $\sim 1.7$ & $\sim 0.8$ vs. RHE & [4] \\
\hline $\mathrm{Pt}-\mathrm{Ni} / \mathrm{CNF} 1: 2$ & - & $\sim 2$ & $\sim 0.7$ vs. RHE & {$[10]$} \\
\hline Pt-Pd (9:1) & 31.59 & 0.67 & - & [13] \\
\hline $\mathrm{Pt}_{3} \mathrm{Pd}_{1}-\mathrm{CeO}_{2} / \mathrm{C}$ & 30.33 & $\sim 4$ & $\sim 1.0$ vs. RHE & [15] \\
\hline Hollow Pt-Ni-Co NDs & 57.0 & 3.8 & $\sim 0.5$ vs. SCE & [17] \\
\hline $\mathrm{PtCoFe}$ & 62.9 & 4.75 & - & [23] \\
\hline $\mathrm{Au}_{41} \mathrm{Cu}_{46} \mathrm{Ni}_{13}$ & 45.8 & 3.8 & - & [25] \\
\hline $\mathrm{PtRuFe} / \mathrm{rGO}$ & 56.4 & 1.33 & - & [45] \\
\hline $\mathrm{Pd}_{59} \mathrm{Fe}_{27} \mathrm{Pt}_{14} \mathrm{NMs}$ & - & 4.36 & - & [50] \\
\hline
\end{tabular}

\subsubsection{Chronoamperometric Study}

The catalytic stability of the catalyst for MOR in acidic media was further investigated by CA. Figure 11 shows the CA curve for the variation in current density with time. As the experiment progresses, the current decay of these catalysts slows down and gradually achieves quasi-steady state [75]. This is due to the formation of oxidation intermediate species such as $\mathrm{CO}, \mathrm{CH}_{3} \mathrm{OH}$, and $\mathrm{CHO}$ [76]. This causes the oxidation of methanol to produce adsorption on the Pt surface to hinder the active site. After testing at $\mathrm{t}=600 \mathrm{~s}$, the current density of $\mathrm{PtNiCo} / \mathrm{rGO} 200\left(65.92 \mathrm{~mA} / \mathrm{cm}^{2}\right)$ is still higher than that of $\mathrm{PtNiCo}$ $\left(8.28 \mathrm{~mA} / \mathrm{cm}^{2}\right), \mathrm{PtNiCo} / \mathrm{rGO} 160\left(45.86 \mathrm{~mA} / \mathrm{cm}^{2}\right), \mathrm{PtNiCo} / \mathrm{rGO} 180\left(29.94 \mathrm{~mA} / \mathrm{cm}^{2}\right)$ and $\mathrm{PtNiCo} / \mathrm{rGO} 220\left(10.83 \mathrm{~mA} / \mathrm{cm}^{2}\right)$. The results show that $\mathrm{PtNiCo} / \mathrm{rGO} 200$ retains the highest steady current density and the highest initial current density when compared to the others. The catalysts supported on rGO show better stability than PtNiCo. This is due to the graphene sheets providing a number of oxygen groups to strengthen the interaction with Pt nanoparticles. As previously indicated, the existence of residual functional groups on reduced graphene oxide also contributes to the catalytic activity [77]. These results 
confirm that $\mathrm{PtNiCo} / \mathrm{rGO} 200$ shows great stability and higher intermediates of poison tolerance as a superior catalyst for MOR in DMFCs.

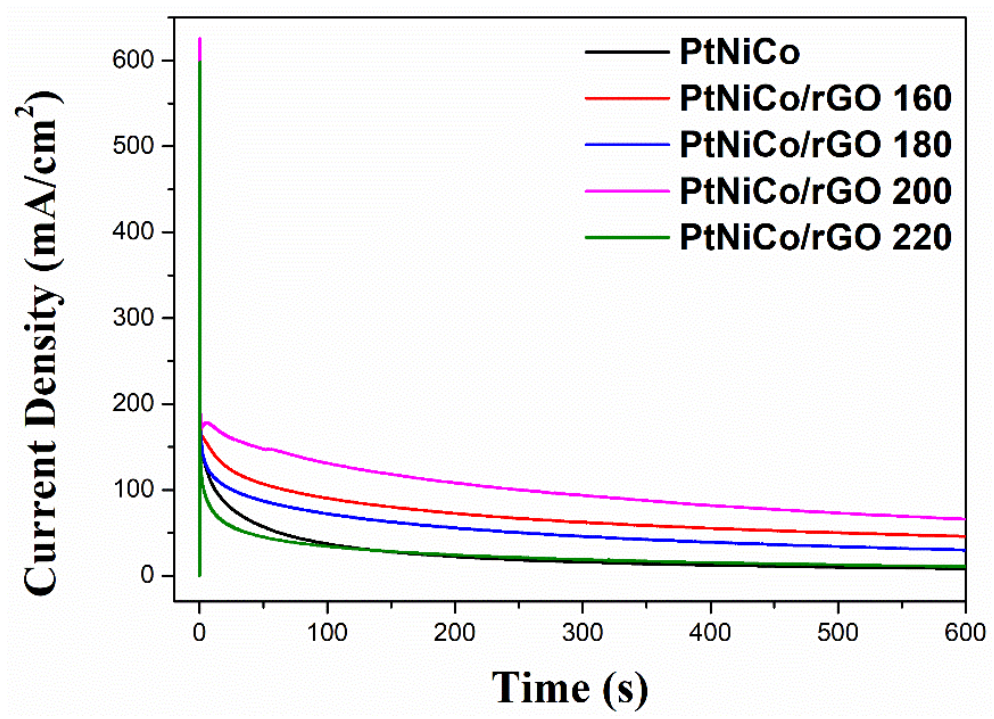

Figure 11. Chronoamperometric curves of PtNiCo, $\mathrm{PtNiCo} / \mathrm{rGO} 160, \mathrm{PtNiCo} / \mathrm{rGO} 180, \mathrm{PtNiCo} / \mathrm{rGO}$ 200, and $\mathrm{PtNiCo} / \mathrm{rGO} 220$ in $0.5 \mathrm{M} \mathrm{H}_{2} \mathrm{SO}_{4}+1.0 \mathrm{M} \mathrm{CH}_{3} \mathrm{OH}$ solution at constant potential of $0.70 \mathrm{~V}$.

\section{Conclusions}

In summary, a ternary alloy structured was prepared with one-step microwaveassisted reduction for uniformly dispersed Pt-Ni-Co nanoparticles supported on rGO. The PtNiCo/rGO exhibited the highest electrochemical properties and the smallest average grain diameter $(17 \mathrm{~nm})$ at a microwave reaction temperature of $200{ }^{\circ} \mathrm{C}$. The aggregation of $\mathrm{PtNiCo}$ is maximally suppressed by the $\mathrm{rGO}$, attributed to the unique two-dimensional flexible microstructure of $\mathrm{rGO}$. In addition, $\mathrm{PtNiCo} / \mathrm{rGO} 200$ had the highest $\mathrm{I}_{\mathrm{D}} / \mathrm{I}_{\mathrm{G}}$ values, indicating an increase in reduction. The $\mathrm{PtNiCo} / \mathrm{rGO}$ nanocomposite presents excellent electrocatalytic ability in terms of high electrocatalytic activity, high poison tolerance, enhanced stability toward MOR compared with PtNiCo. Electrochemical measurements show that $\mathrm{PtNiCo} / \mathrm{rGO} 200$ nanoalloy displays functionality enhancement in both mass and catalytic activities over two times that of the pure PtNiCo catalyst. The unique dispersion of rGO and the synergistic effect between $\mathrm{Pt}, \mathrm{Ni}$, and Co improve the catalytic performance of $\mathrm{PtNiCo} / \mathrm{rGO}$ composites. To satisfy the challenges of rapid fabrication and low environmental impact, we obtained $\mathrm{PtNiCo} / \mathrm{rGO}$ using a rapid synthesis method with a simple process and low-cost precursors. The $\mathrm{PtNiCo} / \mathrm{rGO}$ electrocatalysts have the potential to be used as catalysts with high electrocatalytic activity, $\mathrm{CO}$ resistance, and stability in DMFC. It provides a fast and reduced energy consumption fabrication for designing other high-performance catalysts, which is a great prospect in the application of fuel cell catalyst materials for the future.

Author Contributions: K.-Y.S. conceptualized the idea and designed the experiments; J.-J.W. performed the experiments; K.-Y.S., J.-J.W. and M.-C.T. analyzed the data; K.-Y.S. acquired funding; K.-Y.S., J.-J.W. and M.-C.T. explained and visualized the data and wrote the manuscript. All authors have read and agreed to the published version of the manuscript.

Funding: This work was financially supported by the National Pingtung University of Taiwan (Grant No. NPTU-110-002 and Grant No. NPTU-110-009).

Data Availability Statement: All the data are available within the manuscript.

Conflicts of Interest: The authors declare no conflict of interest. 


\section{References}

1. Liu, M.; Yu, F.; Ma, C.; Xue, X.; Fu, H.; Yuan, H.; Yang, S.; Wang, G.; Guo, X.; Zhang, L. Effective Oxygen Reduction Reaction Performance of FeCo Alloys In Situ Anchored on Nitrogen-Doped Carbon by the Microwave-Assistant Carbon Bath Method and Subsequent Plasma Etching. Nanomaterials 2019, 9, 1284. [CrossRef]

2. Glüsen, A.; Dionigi, F.; Paciok, P.; Heggen, M.; Müller, M.; Gan, L.; Strasser, P.; Dunin-Borkowski, R.E.; Stolten, D. Dealloyed PtNi-Core-Shell Nanocatalysts Enable Significant Lowering of Pt Electrode Content in Direct Methanol Fuel Cells. ACS Catal. 2019, 9, 3764-3772. [CrossRef]

3. Rezaee, S.; Shahrokhian, S.; Amini, M.K. Nanocomposite with Promoted Electrocatalytic Behavior Based on Bimetallic Pd-Ni Nanoparticles, Manganese Dioxide, and Reduced Graphene Oxide for Efficient Electrooxidation of Ethanol. J. Phys. Chem. C 2018, 122, 9783-9794. [CrossRef]

4. Sun, Y.; Du, C.; An, M.; Du, L.; Tan, Q.; Liu, C.; Gao, Y.; Yin, G. Boron-doped graphene as promising support for platinum catalyst with superior activity towards the methanol electrooxidation reaction. J. Power Sources 2015, 300, 245-253. [CrossRef]

5. Noor, T.; Pervaiz, S.; Iqbal, N.; Nasir, H.; Zaman, N.; Sharif, M.; Pervaiz, E. Nanocomposites of NiO/CuO Based MOF with rGO: An Efficient and Robust Electrocatalyst for Methanol Oxidation Reaction in DMFC. Nanomaterials 2020, 10, 1601. [CrossRef]

6. Veizaga, N.S.; Rodriguez, V.I.; Bruno, M.; de Miguel, S.R. The Role of Surface Functionalities in PtGe and PtIn Catalysts for Direct Methanol Fuel Cells. Electrocatalysis 2018, 10, 125-133. [CrossRef]

7. He, M.; Fei, G.; Zheng, Z.; Cheng, Z.; Wang, Z.; Xia, H. Pt Nanoparticle-Loaded Graphene Aerogel Microspheres with Excellent Methanol Electro-Oxidation Performance. Langmuir 2019, 35, 3694-3700. [CrossRef]

8. Menshchikov, V.; Alekseenko, A.; Guterman, V.; Nechitailov, A.; Glebova, N.; Tomasov, A.; Spiridonova, O.; Belenov, S.; Zelenina, N.; Safronenko, O. Effective Platinum-Copper Catalysts for Methanol Oxidation and Oxygen Reduction in Proton-Exchange Membrane Fuel Cell. Nanomaterials 2020, 10, 742. [CrossRef]

9. Arán-Ais, R.M.; Dionigi, F.; Merzdorf, T.; Gocyla, M.; Heggen, M.; Dunin-Borkowski, R.E.; Gliech, M.; Solla-Gullón, J.; Herrero, E.; Feliu, J.M.; et al. Elemental Anisotropic Growth and Atomic-Scale Structure of Shape-Controlled Octahedral Pt-Ni-Co Alloy Nanocatalysts. Nano Lett. 2015, 15, 7473-7480. [CrossRef]

10. Calderón, J.C.; Ráfales, M.R.; Nieto-Monge, M.J.; Pardo, J.I.; Moliner, R.; Lázaro, M.J. Oxidation of CO and Methanol on Pd-Ni Catalysts Supported on Different Chemically-Treated Carbon Nanofibers. Nanomaterials 2016, 6, 187. [CrossRef]

11. Rambabu, G.; Bhat, S.D.; Figueiredo, F.M.L. Carbon Nanocomposite Membrane Electrolytes for Direct Methanol Fuel Cells-A Concise Review. Nanomaterials 2019, 9, 1292. [CrossRef] [PubMed]

12. Higareda, A.; Kumar-Krishnan, S.; García-Ruiz, A.F.; Maya-Cornejo, J.; Lopez-Miranda, J.L.; Bahena, D.; Rosas, G.; Pérez, R.; Esparza, R. Synthesis of Au@Pt Core-Shell Nanoparticles as Efficient Electrocatalyst for Methanol Electro-Oxidation. Nanomaterials 2019, 9, 1644. [CrossRef] [PubMed]

13. Yang, Y.; Cao, Y.; Yang, L.; Huang, Z.; Long, N.V. Synthesis of Pt-Pd Bimetallic Porous Nanostructures as Electrocatalysts for the Methanol Oxidation Reaction. Nanomaterials 2018, 8, 208. [CrossRef] [PubMed]

14. Wang, C.; Zheng, L.; Chang, R.; Du, L.; Zhu, C.; Geng, D.; Yang, D. Palladium-Cobalt Nanowires Decorated with Jagged Appearance for Efficient Methanol Electro-oxidation. ACS Appl. Mater. Interfaces 2018, 10, 29965-29971. [CrossRef] [PubMed]

15. Yousaf, A.B.; Imran, M.; Uwitonze, N.; Zeb, A.; Zaidi, S.J.; Ansari, T.M.; Yasmeen, G.; Manzoor, S. Enhanced Electrocatalytic Performance of $\mathrm{Pt}_{3} \mathrm{Pd}_{1}$ Alloys Supported on $\mathrm{CeO}_{2} / \mathrm{C}$ for Methanol Oxidation and Oxygen Reduction Reactions. J. Phys. Chem. C 2017, 121, 2069-2079. [CrossRef]

16. Huang, J.; Liu, Z.; He, C.; Gan, L.M. Synthesis of PtRu Nanoparticles from the Hydrosilylation Reaction and Application as Catalyst for Direct Methanol Fuel Cell. J. Phys. Chem. B 2005, 109, 16644-16649. [CrossRef]

17. Sriphathoorat, R.; Wang, K.; Shen, P.K. Trimetallic Hollow Pt-Ni-Co Nanodendrites as Efficient Anodic Electrocatalysts. ACS Appl. Energy Mater. 2019, 2, 961-965. [CrossRef]

18. Ghoshal, S.; Jia, Q.; Bates, M.K.; Li, J.; Xu, C.; Gath, K.; Yang, J.; Waldecker, J.; Che, H.; Liang, W.; et al. Tuning Nb-Pt Interactions to Facilitate Fuel Cell Electrocatalysis. ACS Catal. 2017, 7, 4936-4946. [CrossRef]

19. Rethinasabapathy, M.; Kang, S.M.; Haldorai, Y.; Jankiraman, M.; Jonna, N.; Choe, S.R.; Huh, Y.S.; Natesan, B. Ternary PtRuFe nanoparticles supported $\mathrm{N}$-doped graphene as an efficient bifunctional catalyst for methanol oxidation and oxygen reduction reactions. Int. J. Hydrogen Energy 2017, 42, 30738-30749. [CrossRef]

20. Sun, B.; Huang, L.; Su, S.; Luo, S.; Meng, C.; Basit, H.M.A.; Xiao, J.; Bian, T.; Su, S. PtRhCu ternary alloy nanodendrites with enhanced catalytic activity and durability toward methanol electro-oxidation. Mater. Chem. Phys. 2020, 252, 123234. [CrossRef]

21. Sui, N.; Wang, T.; Bai, Q.; Yue, R.; Jiang, H.; Xiao, H.; Liu, M.; Wang, L.; Zhu, Z.; Yu, W.W. Facile synthesis of Ternary Au@PdNi core-shell nanoparticles with enhanced electrocatalytic performance for ethanol oxidation reaction. J. Alloys Compd. 2020, 817, 153335. [CrossRef]

22. Baronia, R.; Goel, J.; Kaswan, J.; Shukla, A.; Singhal, S.K.; Singh, S.P. PtCo/rGO nano-anode catalyst: Enhanced power density with reduced methanol crossover in direct methanol fuel cell. Mater. Renew. Sustain. Energy 2018, 7, 27. [CrossRef]

23. Wang, C.; Zhang, Y.; Zhang, Y.; Xu, P.; Feng, C.; Chen, T.; Guo, T.; Yang, F.; Wang, Q.; Wang, J.; et al. Highly Ordered Hierarchical $\mathrm{Pt}$ and PtNi Nanowire Arrays for Enhanced Electrocatalytic Activity toward Methanol Oxidation. ACS Appl. Mater. Interfaces 2018, 10, 9444-9450. [CrossRef] 
24. Ahmad, Y.H.; Mohamed, A.T.; Youssef, K.M.; Kundu, S.; Mkhoyan, K.A.; Al-Qaradawi, S.Y. Rational synthesis of ternary PtIrNi nanocrystals with enhanced poisoning tolerance for electrochemical ethanol oxidation. Electrochem. Commun. 2019, 101, 61-67. [CrossRef]

25. Ahmad, Y.H.; El-Sayed, H.A.; Mohamed, A.T.; Aljaber, A.S.; Al-Qaradawi, S.Y. Rational one-pot synthesis of ternary PtIrCu nanocrystals as robust electrocatalyst for methanol oxidation reaction. Appl. Surf. Sci. 2020, 534, 147617. [CrossRef]

26. Lee, H.; Park, S.; Kim, H. Preparation of CO-tolerant PtRuNi/C ternary electrocatalyst having a composition gradient shell. Chem. Eng. J. 2021, 414, 128792. [CrossRef]

27. Oh, A.; Sa, Y.J.; Hwang, H.; Baik, H.; Kim, J.; Kim, B.; Joo, S.H.; Lee, K. Rational design of Pt-Ni-Co ternary alloy nanoframe crystals as highly efficient catalysts toward the alkaline hydrogen evolution reaction. Nanoscale 2016, 8, 16379-16386. [CrossRef]

28. Lokanathan, M.; Patil, I.M.; Navaneethan, M.; Parey, V.; Thapa, R.; Kakade, B. Designing of stable and highly efficient ordered $\mathrm{Pt}_{2} \mathrm{CoNi}$ ternary alloy electrocatalyst: The origin of dioxygen reduction activity. Nano Energy 2018, 43, 219-227. [CrossRef]

29. Min, J.; Jeffery, A.A.; Kim, Y.; Jung, N. Electrochemical Analysis for Demonstrating CO Tolerance of Catalysts in Polymer Electrolyte Membrane Fuel Cells. Nanomaterials 2019, 9, 1425. [CrossRef]

30. Bhunia, K.; Khilari, S.; Pradhan, D. Trimetallic PtAuNi Alloy Nanoparticles as an Efficient Electrocatalyst for Methanol Electrooxidation Reaction. Dalton Trans. 2017, 46, 15558-15566. [CrossRef]

31. Sial, M.; Lin, H.; Zulfiqar, M.; Ullah, S.; Ni, B.; Wang, X. Trimetallic PtCoFe Alloy Monolayer Superlattices as Bifunctional Oxygen-Reduction and Ethanol-Oxidation Electrocatalysts. Small 2017, 13, 1700250. [CrossRef]

32. Nugraha, A.S.; Malgras, V.; Kim, J.; Bo, J.; Li, C.; Iqbal, M.; Yamauchi, Y.; Asahi, T. Trimetallic Mesoporous AuCuNi Electrocatalysts with Controlled Compositions Using Block Copolymer Micelles as Templates. Small Methods 2018, 2, 1800283. [CrossRef]

33. Hong, J.W.; Kang, S.W.; Choi, B.S.; Kim, D.; Lee, S.B.; Han, S.W. Controlled Synthesis of Pd Pt Alloy Hollow Nanostructures with Enhanced Catalytic Activities for Oxygen Reduction. ACS Nano 2012, 6, 2410-2419. [CrossRef]

34. Wang, H.; Lu, S.; Xu, W.; Wu, B.; He, G.; Cui, S.; Zhang, Y. Synthesis of a Pt/reduced graphene oxide/polydopamine composite material for localized surface plasmon resonance and methanol electrocatalysis. New J. Chem. 2018, 42, 19458-19466. [CrossRef]

35. Choi, W.; Kim, J.M.; Hwang, C.K.; Choe, M.; Baek, S.; Ban, H.W.; Gu, D.H.; Jeong, H.; Chae, K.H.; Lim, Y.; et al. Thiometallate precursors for the synthesis of supported Pt and PtNi nanoparticle electrocatalysts: Size-focusing by S capping. Nanoscale 2020, 12, 10498-10504. [CrossRef]

36. Wang, P.; Zhang, Y.; Shi, R.; Wang, Z. Shape-Controlled Synthesis of Trimetallic PtPdCu Nanocrystals and Their Electrocatalytic Properties. ACS Appl. Energy Mater. 2019, 2, 2515-2523. [CrossRef]

37. Wang, Y.; Hou, Q.; Ju, M.; Li, W. New Developments in Material Preparation Using a Combination of Ionic Liquids and Microwave Irradiation. Nanomaterials 2019, 9, 647. [CrossRef]

38. Ramasahayam, S.K.; Nasini, U.B.; Bairi, V.; Shaikh, A.U.; Viswanathan, T. Microwave assisted synthesis and characterization of silicon and phosphorous co-doped carbon as an electrocatalyst for oxygen reduction reaction. RSC Adv. 2014, 4, 6306. [CrossRef]

39. Kappe, C.O. Controlled microwave heating in modern organic synthesis. Angew. Chem. Int. Ed. 2004, 43, 6250-6284. [CrossRef]

40. Brunetti, F.G.; Herrero, M.A.; Muñoz, J.d.M.; Dìaz-Ortiz, A.; Alfonsi, J.; Meneghetti, M.; Prato, M.; Vàzquez, E. Microwave-Induced Multiple Functionalization of Carbon Nanotubes. J. Am. Chem. Soc. 2008, 130, 8094-8100. [CrossRef]

41. Hou, S.; He, S.; Zhu, T.; Li, J.; Ma, L.; Du, H.; Shen, W.; Kang, F.; Huang, Z.H. Environment-friendly preparation of exfoliated graphite and functional graphite sheets. J. Mater. 2021, 7, 136-145. [CrossRef]

42. Pipus, G.; Plazl, I.; Koloini, T. Esterification of benzoic acid in microwave tubular flow reactor. Chem. Eng. Sci. 2000, 76, 239-245. [CrossRef]

43. Liao, C.S.; Liao, C.T.; Tso, C.Y.; Shy, H.J. Microwave-polyol synthesis and electrocatalytic performance of Pt/graphene nanocomposites. Mater. Chem. Phys. 2011, 130, 270-274. [CrossRef]

44. Ramirez-Barria, C.S.; Fernandes, D.M.; Freire, C.; Villaro-Abalos, E.; Guerrero-Ruiz, A.; Rodríguez-Ramos, I. Upgrading the Properties of Reduced Graphene Oxide and Nitrogen-Doped Reduced Graphene Oxide Produced by Thermal Reduction toward Efficient ORR Electrocatalysts. Nanomaterials 2019, 9, 1761.

45. Zaaba, N.I.; Foo, K.L.; Hashim, U.; Tan, S.J.; Liu, W.W.; Voon, C.H. Synthesis of Graphene Oxide using Modified Hummers Method: Solvent Influence. Procedia Manuf. 2017, 184, 469-477. [CrossRef]

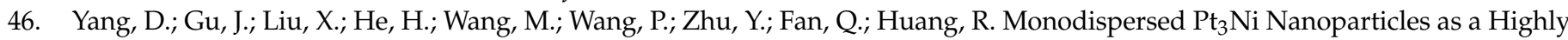
Efficient Electrocatalyst for PEMFCs. Catalysts 2019, 9, 588. [CrossRef]

47. He, F.G.; Yin, J.Y.; Sharma, G.; Kumar, A.; Stadler, F.J.; Du, B. Facile Fabrication of Hierarchical rGO/PANI@PtNi Nanocomposite via Microwave-Assisted Treatment for Non-Enzymatic Detection of Hydrogen Peroxide. Nanomaterials 2019, 9, 1109. [CrossRef]

48. Gao, S.; Yang, X.; Liang, S.; Wang, Y.H.; Zang, H.Y.; Li, Y.G. One step synthesis of PtNi electrocatalyst for methanol oxidation. Inorg. Chem. Commun. 2019, 106, 104-110. [CrossRef]

49. Hu, X.; Song, P.; Yang, X.; Wang, C.; Wang, J.; Tang, Y.; Zhang, J.; Mao, Z. One-step microwave-assisted synthesis of carbonsupported ternary Pt-Sn-Rh alloy nanoparticles for fuel cells. J. Taiwan Inst. Chem. Eng. 2020, 115, 272-278. [CrossRef]

50. Li, G.; Li, J.; Zhou, Z.; Li, C.; Cai, C.; Guo, B.; Priestley, R.D.; Han, L.; Liu, R. Silica-polydopamine core-shell self-confined templates for ultra-stable hollow Pt anchored N-doped carbon electrocatalysts. Dalton Trans. 2017, 46, 16419-16425. [CrossRef]

51. Lokanathan, M.; Patil, I.M.; Kakade, B. Trimetallic PtNiCo nanoflowers as efficient electrocatalysts towards oxygen reduction reaction. Int. J. Hydrogen Energy 2018, 43, 8983-8990. [CrossRef] 
52. Kaewsai, D.; Yeamdee, S.; Supajaroon, S.; Hunsom, M. ORR activity and stability of PtCr/C catalysts in a low temperature/pressure PEM fuel cell: Effect of heat treatment temperature. Int. J. Hydrogen Energy 2018, 43, 5133-5144. [CrossRef]

53. Saloga, P.E.J.; Kästner, C.; Thünemann, A.F. High-Speed but Not Magic: Microwave-Assisted Synthesis of Ultra-Small Silver Nanoparticles. Langmuir 2018, 34, 147-153. [CrossRef]

54. Nassr, A.B.A.A.; Sinev, I.; Pohl, M.M.; Grünert, W.; Bron, M. Rapid microwave-assisted polyol reduction for the preparation of highly active PtNi/CNT electrocatalysts for methanol oxidation. ACS Catal. 2014, 4, 2449-2462. [CrossRef]

55. McGinty, J.; Chong, M.W.S.; Manson, A.; Brown, C.J.; Nordon, A.; Sefcik, J. Effect of Process Conditions on Particle Size and Shape in Continuous Antisolvent Crystallisation of Lovastatin. Crystals 2020, 10, 925. [CrossRef]

56. Clark, M.D.; Kumar, S.K.; Owen, J.S.; Chan, E.M. Focusing Nanocrystal Size Distributions via Production Control. Nano Lett. 2011, 11, 1976-1980. [CrossRef]

57. Kozakova, Z.; Kuritka, I.; Kazantseva, N.E.; Babayan, V.; Pastorek, M.; Machovsky, M.; Bazant, P.; Saha, P. The formation mechanism of iron oxide nanoparticles within the microwave-assisted solvothermal synthesis and its correlation with the structural and magnetic properties. Dalton Trans. 2015, 44, 21099-21108. [CrossRef]

58. Huang, X.; Zhao, Z.; Chen, Y.; Zhu, E.; Li, M.; Duan, X.; Huang, Y. A rational design of carbon-supported dispersive Pt-based octahedra as efficient oxygen reduction reaction catalysts. Energy Environ. Sci. 2014, 7, 2957-2962. [CrossRef]

59. Sreenivasa Kumar, G.; Ramamanohar Reddy, N.; Sravani, B.; Subramanyam Sarma, L.; Veera Reddy, T.; Madhavi, V.; Adinarayana Reddy, S. Ultra-Range Bimetallic Pt-Pd Nanospheres Deposited on Reduced Graphene Sheet as Efficient Electrocatalyst Towards Electrooxidation of Methanol. J. Clust. Sci. 2021, 32, 27-36. [CrossRef]

60. Wang, Z.; Zhang, F.; Liu, Q.; Wang, Z. Electrochemical Synthesis of PtNiCo/3DGN Composite Catalyst and Its Performance for Methanol Electrooxidation. Int. J. Electrochem. Sci. 2017, 12, 10958-10968. [CrossRef]

61. Kasturi, S.; Torati, S.R.; Eom, Y.J.; Ahmad, S.; Lee, B.J.; Yu, J.S.; Kim, C. Real-time monitored photocatalytic activity and electrochemical performance of an $\mathrm{rGO} / \mathrm{Pt}$ nanocomposite synthesized via a green approach. RSC Adv. 2020, 10, 13722. [CrossRef]

62. Mishra, A.; Singh, V.K.; Mohanty, T. Coexistence of interfacial stress and charge transfer in graphene oxide-based magnetic nanocomposites. J. Mater. Sci. 2017, 52, 7677-7687. [CrossRef]

63. Marinoiu, A.; Andrulevicius, M.; Tamuleviciene, A.; Tamulevicius, T.; Carcadea, E.; Raceanu, M.; Varlam, M. High performance catalytic system with enhanced durability in PEM fuel cell. Int. J. Hydrogen Energy 2020, 45, 10409-10422. [CrossRef]

64. Antony, R.P.; Preethi, L.K.; Gupta, B.; Mathews, T.; Dash, S.; Tyagi, A.K. Efficient electrocatalytic performance of thermally exfoliated reduced graphene oxide-Pt hybrid. Mater. Res. Bull. 2015, 70, 60-67. [CrossRef]

65. Woo, J.H.; Park, S.J.; Chung, S.; Kim, S. Effect of polydopamine-modified reduced graphene oxides on the catalytic activity of Pt nanoparticles catalysts for fuel cell electrodes. Carbon Lett. 2019, 29, 47-55. [CrossRef]

66. Ji, W.; Qi, W.; Tang, S.; Peng, H.; Li, S. Hydrothermal Synthesis of Ultrasmall Pt Nanoparticles as Highly Active Electrocatalysts for Methanol Oxidation. Nanomaterials 2015, 5, 2203-2211. [CrossRef] [PubMed]

67. Luo, X.; Liu, C.; Wang, X.; Shao, Q.; Pi, Y.; Zhu, T.; Li, Y.; Huang, X. Spin Regulation on 2D Pd-Fe-Pt Nanomeshes Promotes Fuel Electrooxidations. Nano Lett. 2020, 20, 1967-1973. [CrossRef]

68. Liu, Y.; Wang, Y.; Zhang, J.; Shi, S.; Feng, P.; Wang, T. Observation of surface structural changes of Pt octahedron nanoparticles and its effect in electrocatalysis oxidation of methanol. Catal. Commun. 2009, 10, 1244-1247. [CrossRef]

69. Marinoiu, A.; Raceanu, M.; Carcadea, E.; Andrulevicius, M.; Tamuleviciene, A.; Tamulevicius, T.; Capris, C.; Varlam, M. Efficient method to obtain Platinum-Cobalt supported on graphene oxide and electrocatalyst development. Int. J. Hydrogen Energy 2020, 45, 26226-26237. [CrossRef]

70. Baronia, R.; Goel, J.; Tiwari, S.; Singh, P.; Singh, D.; Singh, S.P.; Singhal, S.K. Efficient electro-oxidation of methanol using PtCo nanocatalysts supported reduced graphene oxide matrix as anode for DMFC. Int. J. Hydrogen Energy 2017, 42, 10238-10247. [CrossRef]

71. Wei, L.; Wu, Q.; Yang, Y.; Jiang, B.; Sun, G.; Feng, J.; Yu, F.; Kang, Y.; Dong, G. One-step synthesis of nitrogen-decorated $\mathrm{CeO}_{2}$ /reduced graphene oxide nanocomposite and its electrocatalytic activity for triiodide/iodide reduction. Mater. Res. Lett. 2020, 35, 1461-1471. [CrossRef]

72. Wang, X.; Zhang, X.; He, X.; Ma, A.; Le, L.; Lin, S. Facile Electrodeposition of Flower-Like PMo 12 -Pt/rGO Composite with Enhanced Electrocatalytic Activity towards Methanol Oxidation. Catalysts 2015, 5, 1275-1288. [CrossRef]

73. Wang, Z.; Hu, S.; Ali, A.; Chen, H.; Shen, P.K. Facile One-Pot Synthesis of a PtRh Alloy Decorated on Ag Nanocubes as a Trimetallic Core-Shell Catalyst for Boosting Methanol Oxidation Reaction. ACS Appl. Energy Mater. 2021, 4, 1085-1092. [CrossRef]

74. Jia, Z.; Wang, Y.; Qi, T. Pd nanoparticles supported on $\mathrm{Mg}-\mathrm{Al}-\mathrm{CO}_{3}$ layered double hydroxide as an effective catalyst for methanol electro-oxidation. RSC Adv. 2015, 5, 62142. [CrossRef]

75. Yang, Y.; Huang, H.; Yang, C.; He, H. Ultrafine Rh-Decorated 3D Porous Boron and Nitrogen Dual-Doped Graphene Architecture as an Efficient Electrocatalyst for Methanol Oxidation Reaction. ACS Appl. Energy Mater. 2021, 4, 376-383. [CrossRef]

76. Song, C.; Kim, S. Preparation and Electrochemical Characterization of Pt-Supported Flake-like Graphitic Carbon Nitride on Reduced Graphene Oxide as Fuel Cell Catalysts. J. Electrochem. Soc. 2015, 162, F1181-F1190. [CrossRef]

77. Kundu, P.; Nethravathi, C.; Deshpande, P.A.; Rajamathi, M.; Madras, G.; Ravishankar, N. Ultrafast Microwave-Assisted Route to Surfactant-Free Ultrafine Pt Nanoparticles on Graphene: Synergistic Co-reduction Mechanism and High Catalytic Activity. Chem. Mater. 2011, 23, 2772-2780. [CrossRef] 